\title{
Idaho Radionuclide Exposure Study- Literature Review
}

E. G. Baker

H. D. Freeman

J. N. Hartley

October 1987

Prepared for

the U.S. Environmental Protection Agency

Office of Radiation Programs

under a Related Services Agreement

with the U.S. Department of Energy

Contract DE-AC06-76RLO 1830

Pacific Northwest Laboratory

Operated for the U.S. Department of Energy

by Battelle Memorial Institute 
Although the research described in this article has been funded wholly or in part by the United States Environmental Protection Agency (EPA), it has not been subjected to EPA review and therefore does not necessarily reflect the views of EPA and no official endorsement should be inferred.

\title{
DISCLAIMER
}

This report was prepared as an account of work sponsored by an agency of the United States Government. Neither the United States Government nor any agency thereof, nor Battelle Memorial Institute, nor any of their employees, makes any warranty, expressed or implied, or assumes any legal liability or responsibility for the accuracy, completeness, or usefulness of any information, apparatus, product, or process disclosed, or represents that its use would not infringe privately owned rights. Reference herein to any specific commercial product, process, or service by trade name, trademark, manufacturer, or otherwise, does not necessarily constitute or imply its endorsement, recommendation, or favoring by the United States Government of any agency thereof, or Battelle Memorial Institute. The views and opinions of authors expressed herein do not necessarly state or reflect those of the United States Government or any agency thereof, or Battelle Memorial Institute.

\author{
PACIFIC NORTHWEST LABORATORY \\ operated by \\ BATTELLE MEMORIAL INSTITUTE \\ for the \\ UNITED STATES DEPARTMENT OF ENERGY \\ under Contract DE-AC06-76RLO 1830
}

\begin{tabular}{|c|c|}
\hline \multicolumn{2}{|c|}{ Printed in the United States of America } \\
\hline \multicolumn{2}{|c|}{ Available from } \\
\hline \multicolumn{2}{|c|}{ National Technical Information Service } \\
\hline \multicolumn{2}{|c|}{ United States Department of Commerce } \\
\hline \multicolumn{2}{|c|}{$\begin{array}{l}5285 \text { Port Royal Road } \\
\text { Soring }\end{array}$} \\
\hline \multirow{2}{*}{\multicolumn{2}{|c|}{$\begin{array}{l}\text { NTIS Price Codes } \\
\text { Microfiche A01 }\end{array}$}} \\
\hline & \\
\hline \multicolumn{2}{|c|}{ Printed Copy } \\
\hline & Price \\
\hline Pages & Codes \\
\hline 001-025 & $\mathrm{A} 02$ \\
\hline 026-050 & $\mathrm{A} 03$ \\
\hline 051-075 & A04 \\
\hline 076-100 & A05 \\
\hline $101-125$ & A06 \\
\hline $126-150$ & A07 \\
\hline $151-175$ & $A 0 B$ \\
\hline $176-200$ & A09 \\
\hline $201-225$ & A010 \\
\hline $226-250$ & A011 \\
\hline $251-275$ & A012 \\
\hline $276-300$ & A013 \\
\hline
\end{tabular}


PNL -6358

$\mathrm{UC}+13$

IDAHO RADIONUCLIDE EXPOSURE STUDY--

LITERATURE REVIEW

E. G. Baker

H. 0. Freeman

J. N. Hartley

October 1987

Prepared for the U.S. Environmental Protection Agency Office of Radiation Programs Las Vegas, Nevada under a Related Services Agreement with the U.S. Department of Energy Contract DE-AC06-76RL0 1830

Pacific Northwest Laboratory Richland, Washington 99352 


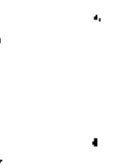


SUMMARY

Phosphate ores contain elevated leveis of natural radioactivity, some of which is released to the environment during processing or use of solid byproducts. In the Western states, most of the phosphate rock is produced in the State of Idaho. Four phosphate processing plants are located in southeastern Idaho. Two thermal process plants, one located near soda Springs (Monsanto Co.) and the other near Pocatello (FMC Corporation), produce elemental phosphorus. A wet process plant (J. R. Simplot Co.) producing phosphoric acid and a variety of fertilizers is in operation near Pocatello. A second wet process plant (Beker Industries) located in Conda near Soda Springs is currently shut down.

The effect of radionuclides from Idaho phosphate processing operations on the local communities has been the subject of much research and study. The literature is reviewed in this report. Two primary radionuclide pathways to the environment have been studied in detail:

- airborne release of volatile radionuclides, primarily 210 po, from calciner stacks at the two elemental phosphorus plants

- use of byproduct slag as an aggregate for construction in Soda Springs and Pocatello.

The health impact of both pathways has been estimated by the U.S. Environmental Protection Agency (EPA) (210 Po) and the Idaho Department of Health and Weifare $(s) \mathrm{ag})$. The EPA has issued a standard of $21 \mathrm{Ci} /$ year of $210_{\text {Po enissions from }}$ calciner stacks. Since 1977, the State of Idaho has forbidden use of slag as a construction material in habitable structures; it is still used for other construction activities, mainly in road construction and for railroad ballast.

Despite the research, there is still no clear understanding of the population dose from radionuclide emissions, effluents, and solid wastes from phosphate processing plants. Two other potential radionuclide pathways to the environment have been identified: radon exhalation from phosphogypsum and ore piles and contamination of surface and ground waters. Recommendations on further study needed to develop a data base for a complete risk assessment are given in the report. 
.

,

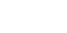

( 


\section{ACKNOWLEDGMENTS}

The authors would like to express their appreciation to the many individuals who provided material and comments for this report. Special thanks are extended to Jack Peterson, Idaho Mining Association, for providing the initial bibliography and references; Marc Bowman, FMC Corporation, who provided a large number of the documents reviewed in this report; and Earl Mapes, J. R. Simplot Co., for his thorough review and comments on the report. The authors would also like to thank the EPA Office of Radiation Programs staff for their support and comments. 


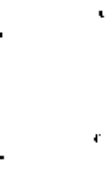

- 


\section{CONTENTS}

SUMMARY

$i \mathrm{i}$

ACKNOWLEDGMENTS

1.0 INTRODUCTION

1.1

2.D IDAHO PHOSPHATE INDUSTRY

2.1

2.1 MINES

2.1

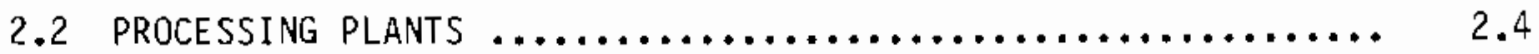

3.0 RADIONUClide EMISSIONS fROM PHOSPHATE PROCESSING PLANTS ........ 3.1

3.1 WET PROCESS PHOSPHORIC ACID AND FERTILIZER PRODUCTION ...... 3.2

3.1 .1 Process Description $\ldots \ldots \ldots \ldots \ldots \ldots \ldots \ldots \ldots \ldots \ldots . \ldots \ldots . . \ldots \ldots$

3.1.2 Radionuclide Pathways to the Environment .......... 3.3

3.1.3 Radionuclide Material Balance ................. 3.9

3.2 THERMAL PROCESS FOR PROOUCTION OF ELEMENTAL PHOSPHORUS $\ldots \ldots . . .12$

3.2.1 Process Description ....................... 3.12

3.2.2 Radionuclide Pathways to the Environment .......... 3.14

3.2.3 Radionuclide Material Baiance ................. 3.20

4.0 ENVIRONMENTAL RADIOACTIVITY FROM PHOSPHATE PROCESSING PLANTS $\ldots \ldots .4 .1$

4.1 AIRBORNE RADIONUCLIDES $\ldots \ldots \ldots \ldots \ldots \ldots \ldots \ldots \ldots \ldots \ldots \ldots \ldots \ldots \ldots \ldots \ldots \ldots \ldots \ldots \ldots$

4.2 DISTRIBUTION OF RADIONUCLIDES FROM COMMERCIAL USE
OF BYPRODUCTS $\ldots \ldots \ldots \ldots \ldots \ldots \ldots \ldots \ldots \ldots \ldots \ldots \ldots \ldots \ldots \ldots \ldots \ldots \ldots \ldots$

4.3 RADIONUCLIDES IN WATER $\ldots \ldots \ldots \ldots \ldots \ldots \ldots \ldots \ldots \ldots \ldots \ldots \ldots \ldots$

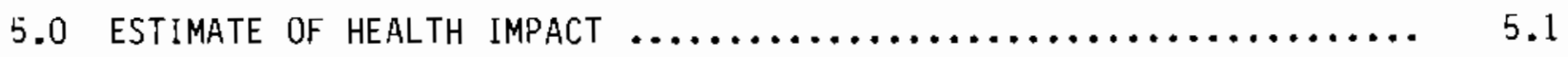

5.1 AIRBORNE RADIONUCLIDES FROM THERMAL PROCESS PLANTS ........ 5.1

5.2 GAMMA AND RADON/PROGENY EXPOSURE FROM SLAG $\ldots \ldots \ldots \ldots \ldots \ldots . .2$

5.3 RADIONUCLIDE EMISSIONS FROM WET PROCESS PLANTS $\ldots \ldots \ldots \ldots \ldots . . . . .5$

6.0 CONCLUSIONS AND RECOMMENDATIONS $\ldots \ldots \ldots \ldots \ldots \ldots \ldots \ldots \ldots \ldots \ldots \ldots . \ldots \ldots$ 


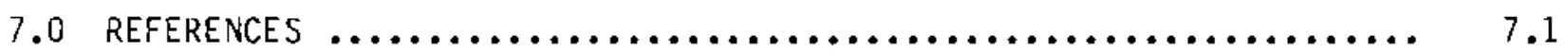
APPENDIX A $-238_{\mathrm{U}}$ AND ${ }^{232}$ Th DECAY SERIES ........................ A.1 APPENDIX B - GLOSSARY OF TERMS AND ABBREVIATIONS $\ldots \ldots \ldots \ldots \ldots \ldots \ldots \ldots$ B. 1 APPENDIX C - BIBLIOGRAPHY $\ldots \ldots \ldots \ldots \ldots \ldots \ldots \ldots \ldots \ldots \ldots \ldots \ldots \ldots \ldots \ldots \ldots \ldots \ldots \ldots \ldots . .1$ 


\section{FIGURES}

2.1 Idaho Phosphate Operations $\ldots \ldots \ldots \ldots \ldots \ldots \ldots \ldots \ldots \ldots \ldots, 2.2$

2.2 Aerial View of the Pocatello Area Showing the J. R. Simplot Co. Fertilizer Complex and the FMC Elemental Phosphorus Plant ...... 2.5

2.3 Aerial View of the Monsanto Elemental Phosphorus Plant and Soda

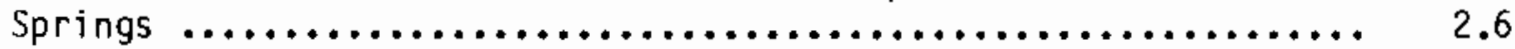

3.1 Aerial View of the J. R. Simplot Co. Wet Process Fertilizer Complex Near Pocatello ............................. 3.2

3.2 Radionuclide Pathways to the Environment for a Wet Process Plant ..................................... 3.4

3.3 Monsanto Elemental Phosphorus Plant Near Soda Springs ......... 3.13

3.4 FMC Elemental Phosphorus Plant Near Pocatello ............... 3.13

3.5 Radionuclide Pathways to the Environment for a Thermal Process Plant ...................................... 3.15

3.6 Radionuclide Material Balance for a Thermal Process Plant ...... 3.2l

4.1 Gross Alpha Air Concentrations, $1974 \ldots \ldots \ldots \ldots \ldots \ldots \ldots \ldots \ldots \ldots . . \ldots . . . \ldots$

4.2 Sampling Locations in the Pocatello Area .................. 4.3

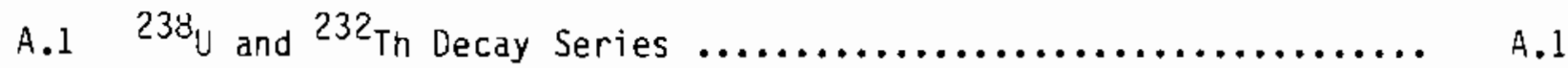


TABLES

2.1 Phosphate Rock Mines in Idaho $\ldots \ldots \ldots \ldots \ldots \ldots \ldots \ldots \ldots \ldots \ldots \ldots \ldots . . \ldots \ldots$

2.2 Phosphate Processing Plants in Idaho ...................... 2.4

3.1 Radionuclide Content of Phosphate Rock Used in Idaho

Processing Plants ........................................ 3.1

3.2 Particulate Emissions from Phosphate Rock Calciners at

Wet Process Plants .................................... 3.6

3.3 Radionuclide Concentration in Phosphogypsum Solids ........... 3.8

3.4 Phosphogypsum Piles in Idaho ......................... 3.8

3.5 Radionuclide Content of Process Waters at Wet Process

Phosphoric Acid Plant ................................. 3.10

3.6 Radionuclide Content of Outfall and Incoming Water at

J. R. Simplot Co. Plant ................................ 3.11

3.7 Radionuclide Content of Fertilizer Products $\ldots \ldots \ldots \ldots \ldots \ldots \ldots \ldots \ldots . . \ldots$

3.8 Radionuclide Content of Phosphate Rock Feedstock and Calcined

Product at Idaho Elemental Phosphorus Plants ................. 3.15

3.9 Airborne Emissions from Phosphate Rock Calciners at Elemental

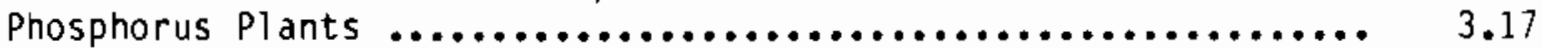

3.10 Concentration of Radionuclides in Slags from Idaho ............. 3.19

4.1 Average Annual Lung Dose for Insoluble Radionuclides .......... 4.4

Radionuclide Activity of Surface Sofl Samples from the
Pocatello Area $\ldots \ldots \ldots \ldots \ldots \ldots \ldots \ldots \ldots \ldots \ldots \ldots \ldots \ldots \ldots \ldots \ldots \ldots$

4.3 Distribution of Radium in Environs from the Commercial Use of Slag--Pocatello Area, 1974 ........................... 4.6

4.4 Distribution of Radium in Environs from the Commercial Use of Slag--Soda Springs Area, 1972-74 ..................... 4... 4

4.5 Gamma Survey, Pocatello Area ............................ 4.8

4.6 Beta Activity and $40_{K}$ Concentration in wells Near the

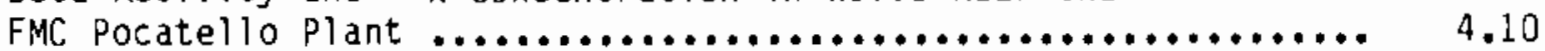

5.1 Input Data Used in Dose and Risk Calculations ................ 5.. 
5.2 Estimate of Radiation Dose and Fatal Cancer from Airborne Radionuclide Emissions from Calciners at Elemental Phosphorus Plants

5.3 Airborne Radionuclide Particulate Emissions from Wet Process

5.4 Health Impact of Airborne Radionuclide Particulate Emissions from a Wet Process Phosphoric Acid Plant 


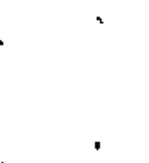




\subsection{INTRODUCTION}

Phosphate ores contain approximately 60 times the levels of natural radioactivity normally found in the earth's crust. Some of the radioactivity is released to air and water during processing of the ores, and some is distributed in the environment through the use of solid byproduct wastes. In 1979, the U.S. Environmental Protection Agency (EPA) listed radionuclides as hazardous air pollutants and was further required by the Clean Air Act to issue emission standards. In February 1985, the EPA issued a radionuclide standard of $21 \mathrm{Ci} /$ year of 210 po air emission per elemental phosphorus plant under orders of the North District of California, U.S. District Court. This standard was based on partial EPA studies satisfying the court orders for regulation under Section 112 of the Clean Air Act.

The communities of Soda Springs and Pocatello, Idaho, are immediately adjacent to elemental phosphorus and phosphate fertilizer plants containing stockpiles of slag, phosphogypsum, (a) and phosphate ore. Furthermore, slag containing elevated concentrations of naturally occurring radionuclides has been used as an aggregate material for paving and building throughout these communities.

This report is the first phase of a program to evaluate the impact of radioactive air emissions, water effluent, and solid wastes from the phosphorus processing plants in southeastern Idaho. The objective of this literature review is to identify radionuclide source terms and pathways to the environment from phosphate processing plants in Idaho and to determine additional information needed to assess the total radionuclide exposure from these plants and from natural sources in the area.

Radionuclides present in phosphate ore are in the ${ }^{238} \mathrm{U}$ and ${ }^{232} \mathrm{Th}$ decay series. Members of these series are shown in Appendix A. Emphas is in the research to date has been on $210 \mathrm{Po}_{0}$, a volatile radionuclide in the $238 \mathrm{U}$ series, which is known to be emitted from elemental phosphorus plants. However, other members are also of concern. A variety of terms dealing with radioactivity,

(a) Solid byproduct of the wet process; primarily calcium sulfate. 
radionuclides, and phosphate processing are used throughout this report. A glossary of terms and abbreviations is included as Appendix $B$. Appendix $C$ is a bibliography of literature reviewed during the preparation of this report. 


\subsection{IOAHO PHOSPHATE INOUSTRY}

The phosphate industry in Idaho is an integrated operation from mining to production of phosphorus, phosphoric acid, and fertilizers. The locations of phosphate operations in Idaho are shown in Figure 2.1.

Over the past 10 years, phosphate rock production [based on phosphorus pentoxide $\left.\left(\mathrm{P}_{2} \mathrm{O}_{5}\right)\right]$ in the Western states has been 6 to 7 million tons (a) per year, of which Idaho produced about $80 \%$. The bulk of phosphate rock has been produced in the Southern states, however. For example, in 1984, the total U.S. production was 163 million tons with about 90\% coming from Florida and North Carolina.

In the past, domestic demand for phosphate rock had been expected to grow $1 \%$ to $3 \%$ per year with exports increasing at an even faster rate (Powell 1974; Chemical Marketing Reporter 1981, 1983). In actuality, no growth has been observed over the last 10 years, and phosphorus production capacity has actually declined.

\subsection{MINES}

A11 of Idaho's production comes from seven mines in Bingham and Caribou counties in the southeastern part of the state (Table 2.1). These mines are operated by the following companies: J. R. Simplot Co.; Beker Industries; Western Cooperative Fertilizers, Ltd, Canada; Monsanto Co.; Stauffer Chemical Co.; and Alumet. The J.R. Simplot Co. operates the Gay Mine on the Fort Hall Indian Reservation. About 1.2 million tons per year of low-grade overburden (24.5\% $\mathrm{P}_{2} \mathrm{O}_{5}$ ) from the Gay Mine supplies the FMC elemental phosphorus plant at Pocatello. About 0.4 million tons per year of deeper, higher grade ore are shipped to the J. R. Simplot Co. wet process phosphoric acid fertilizer complex in Pocatello. The J. R. Simplot Co. recently began production at the Smoky Canyon Mine, which replaced the nearly exhausted Woodall Peak Mine. The ore goes to the wet process plants at Pocatello and California.

(a) Unless indicated otherwise, "tons" refers to metric tons. 


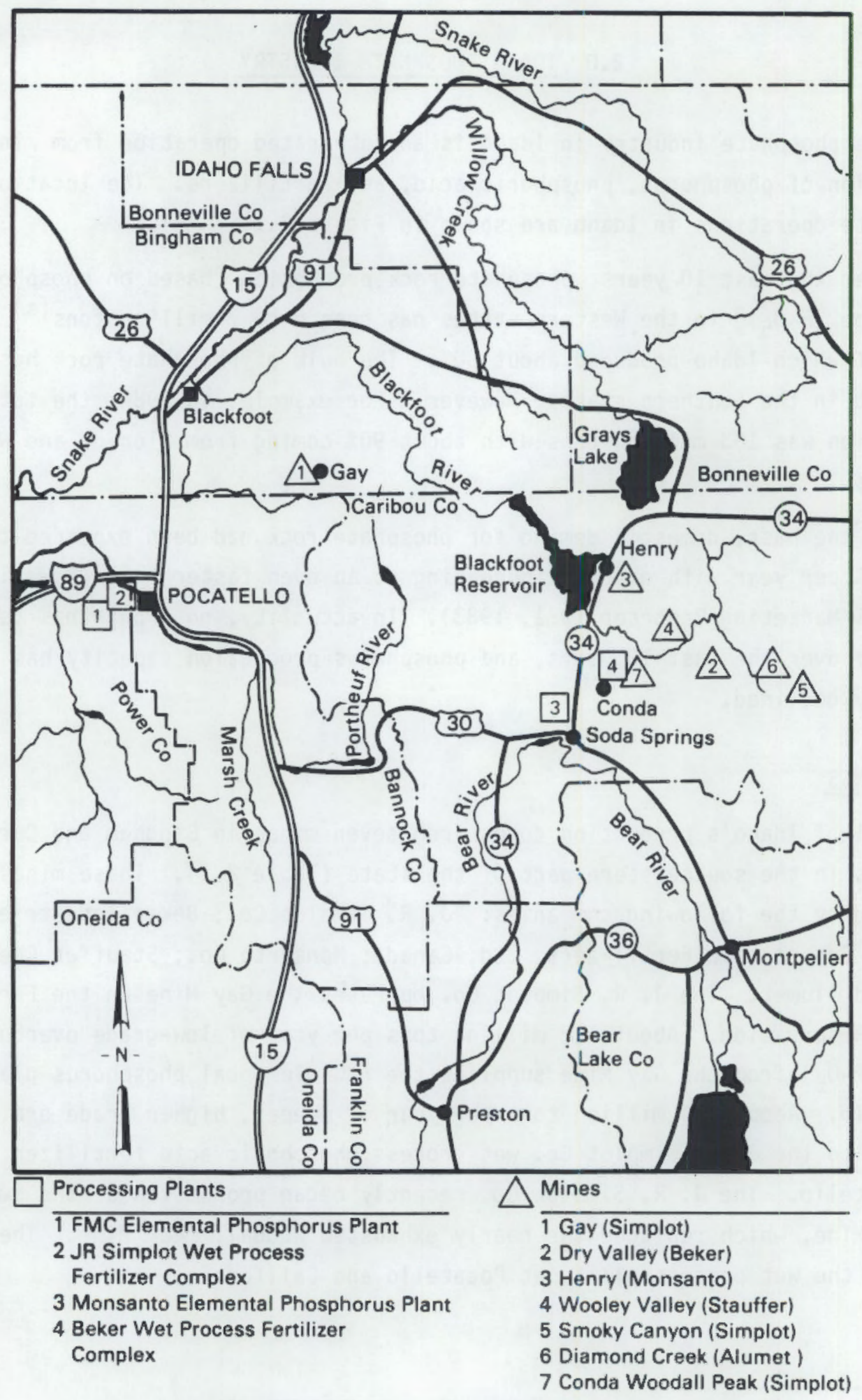

FIGURE 2.1. Idaho Phosphate Operations 
TABLE 2.1. Phosphate Rock Mines in Idaho

\begin{tabular}{|c|c|c|c|c|}
\hline Mine & Location & Operator & $\begin{array}{r}\text { Production } \\
\text { Capacity } \\
10^{6} \text { TPY (a) } \\
\end{array}$ & Destination \\
\hline Gay & Fort Hall & J. R. Simplot Co. & 1.6 & $\begin{array}{l}\text { FMC, Pocatello; } \\
\text { J. R. Simplot Co., } \\
\text { Pocatello }\end{array}$ \\
\hline Dry Valley & NE of Conda & $\begin{array}{l}\text { Beker Industries } \\
\text { Western } \\
\text { Cooperative }\end{array}$ & 1.8 & $\begin{array}{l}\text { Beker Industries, } \\
\text { Conda; } \\
\text { Alberta, Canada }\end{array}$ \\
\hline Henry & $\begin{array}{l}\text { N of Soda } \\
\text { Springs }\end{array}$ & Monsanto & 0.8 & $\begin{array}{l}\text { Monsanto, } \\
\text { Soda Springs }\end{array}$ \\
\hline Wooley Valley & $\begin{array}{l}\text { NE of Soda } \\
\text { Springs }\end{array}$ & Stauffer & 0.7 & $\begin{array}{l}\text { Stauffer, } \\
\text { Silver Bow, } \\
\text { Montana }\end{array}$ \\
\hline Smoky Canyon & $\begin{array}{l}30 \mathrm{miles} \\
\text { east of } \\
\text { Conda }\end{array}$ & J. R. Simplot Co. & -- & $\begin{array}{l}\text { J. R. Simplot Co., } \\
\text { Pocatello } \\
\text { California }\end{array}$ \\
\hline $\begin{array}{l}\text { Di amond } \\
\text { Creek }\end{array}$ & $\begin{array}{l}\text { NE of Soda } \\
\text { Springs }\end{array}$ & Alumet & -- & -- \\
\hline Woodall Peak & Conda & J. R. Simplot Co. & -- & $\cdots$ \\
\hline
\end{tabular}

(a) Tons per year.

The Dry Valley Mine northeast of Conda is operated by the Conda Partnership, a 50/50 association between Beker Industries and Western Cooperative Fertilizers, LTD, Canada. Beker Industries' share of the mined rock was used in its adjacent wet process fertilizer complex at Conda; this plant is currently shut down. Western Cooperative's share is exported to Alberta.

Monsanto obtains phosphate rock for its elemental phosphorus plant in Soda Springs from the Henry Mine near the village of Henry north of Soda Springs. Stauffer operates the Wooley Valley Mine northeast of Soda Springs to produce rock for its elemental phosphorus plant in Silver Bow, Montana. 


\subsection{PROCESSING PLANTS}

The four phosphate processing plants in Idaho and their capacities are listed in Table 2.2. Two processing plants are located near Pocatello (Figure 2.2). The city is triangular-shaped and nestled in a large draw in the Pocatello Range at an altitude of $4500 \mathrm{ft}$. It is bounded on the west by adjacent mountains and on the east by adjacent mountains with a more gentle rise. The town of Chubbock, a suburb of Pocatello, lies to the northwest on flatlands. The FMC elemental phosphorus plant and the J. R. Simplot Co. fertilizer plants are located about 3 miles northwest of Pocatello at an elevation of $4500 \mathrm{ft}$ at the base of the mountain that bounds the west side of the city. Phosphogypsum waste and slag are deposited on the mountain side about $150 \mathrm{ft}$ above the plants.

The Monsanto elemental phosphorus plant (Figure 2.3) and the Beker Industries wet process fertilizer complex are located near Soda Springs. The city of Soda Springs is adjacent to the Bear River at an altitude of $6000 \mathrm{ft}$. It is bounded by Chester Hill (6500 ft) to the north-northwest and Rabbit Mountain $(6700 \mathrm{ft}) 1.5 \mathrm{miles}$ to the east-northeast. The elemental phosphorus plant is located 1.5 miles north-northwest of town at an altitude of $6000 \mathrm{ft}$. The fertilizer plant at Conda (currently shut down) is located 6 miles northeast of Soda Springs in the foothills of the Aspen Range at an altitude of $6200 \mathrm{ft}$.

\section{TABLE 2.2. Phosphate Processing Plants in Idaho}

\begin{tabular}{|c|c|c|c|c|}
\hline Company & Location & Type of Process & \multicolumn{2}{|c|}{ Production Capacity, TPY(a) } \\
\hline $\begin{array}{l}\text { Beker } \\
\text { Industries (b) }\end{array}$ & Conda & Wet Process & $\begin{array}{r}270,000 \\
64,000\end{array}$ & $\begin{array}{l}\text { Phosphoric Acid } \\
\text { Superphosphoric Acid }\end{array}$ \\
\hline $\begin{array}{l}\text { J. R. Simplot } \\
\text { Co. }\end{array}$ & Pocatello & Wet Process & $\begin{array}{r}326,000 \\
75,000\end{array}$ & $\begin{array}{l}\text { Phosphoric Acid } \\
\text { Superphosphoric Acid }\end{array}$ \\
\hline FMC & Pocatello & Elemental & 137,000 & \\
\hline Monsanto & Soda Springs & Elemental & 95,000 & \\
\hline
\end{tabular}

\footnotetext{
(a) (Metric) tons per year; based on $\mathrm{P}_{2} \mathrm{O}_{5}$ for wet process plants and $\mathrm{P}_{4}$ for elemental phosphorus plants.

(b) Currently shut down.
} 


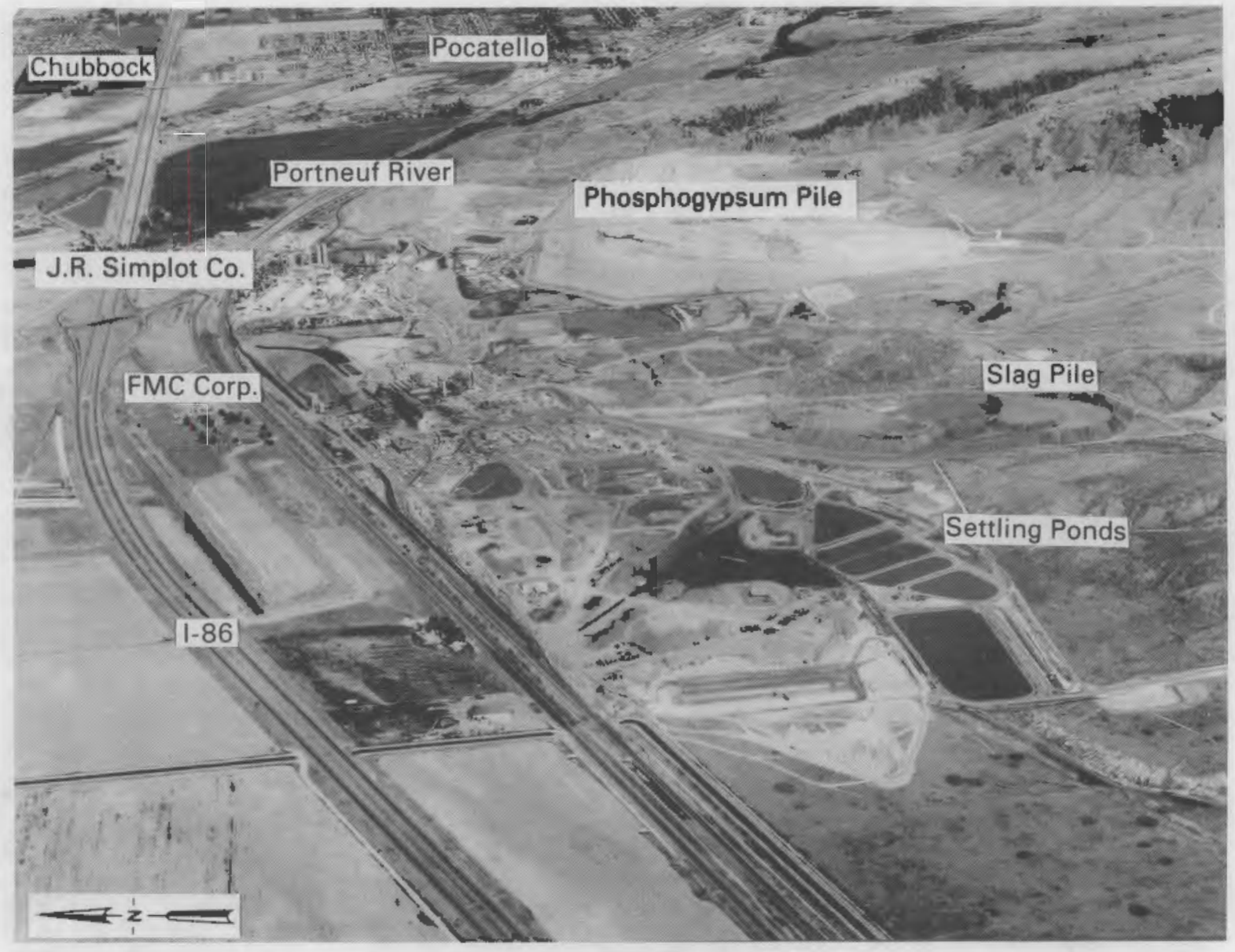

FIGURE 2.2. Aerial View of the Pocatello Area Showing the J.R. Simplot Co. Fertilizer Complex and the FMC Elemental Phosphorus Plant 


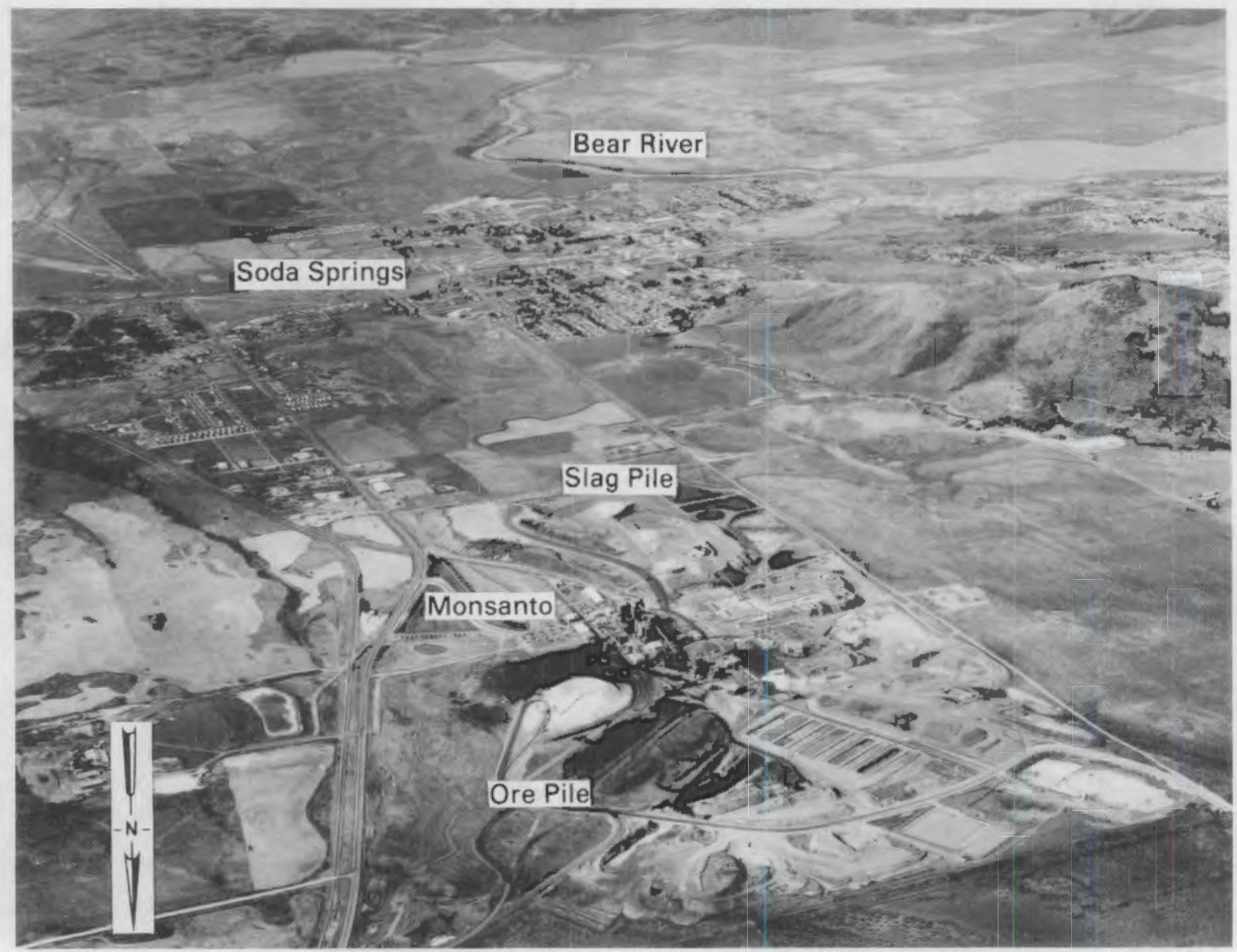

FIGURE 2.3. Aerial View of the Monsanto Elemental Phosphorus Plant and Soda Springs 


\subsection{RADIONUCLIDE EMISSIONS FROM PHOSPHATE PROCESSING PLANTS}

The four phosphate processing plants in Idaho (1 isted in Table 2.2) are of two types: wet process and thermal process. The Beker Industries plant at Conda and the J. R. Simplot Co. plant at Pocatello are wet process plants that use high-grade ore $\left(\begin{array}{lll}\sim 11 \% & P_{2} 0_{5}\end{array}\right)$ to produce phosphoric acid, which in turn is used to make a wide variety of fertilizers. Low-quality ore $\left(\sim 24 \% \mathrm{P}_{2} \mathrm{O}_{5}\right)$ is converted to elemental phosphorous at FMC's plant in Pocatello and Monsanto's plant in Soda Springs, both thermal process plants.

Table 3.1 shows the radionuclide content of some of the phosphate ores used in the processing plants. The ${ }^{238} \mathrm{U}$ concentration is in the range of 20 to $40 \mathrm{pCi} / \mathrm{g}$ and, except for the blended Monsanto feedstock, is in equilibrium with its progeny $\left({ }^{234} \mathrm{U},{ }^{230} \mathrm{Th},{ }^{226} \mathrm{Ra},{ }^{210} \mathrm{~Pb}\right.$, and $\left.{ }^{210} \mathrm{Po}\right)$. Concentrations of other radionuclides in the ${ }^{235} \mathrm{U}$ and ${ }^{232} \mathrm{Th}$ series are low.

Radionuclides from phosphate processing can be released to the environment through several different pathways, which vary depending on the type of processing plant. A brief description of each type of plant is given here, and radionuclide pathways to the environment are identified.

TABLE 3.1. Radionuclide Content of Phosphate Rock Used in Idaho Processing Plants, pCi/g (Eadie and Bernhardt 1977; Eadie, Bernhardt, and Boyson 1978; EPA 1984b,c)

\begin{tabular}{|c|c|c|c|c|c|}
\hline Radionuclide & $\begin{array}{l}\text { Conda, } \\
\text { J. R. Simplot Co. }\end{array}$ & $\begin{array}{l}\text { Gay, } \\
\text { J. R. Simplot Co. }\end{array}$ & $\begin{array}{l}\text { Gay, } \\
\text { FMC }\end{array}$ & $\begin{array}{l}\text { Gay, } \\
\text { FMC } \\
\end{array}$ & $\begin{array}{l}\text { Blended, } \\
\text { Monsanto } \\
\end{array}$ \\
\hline $238_{U}$ & $<20$ & 26 & 22 & 21 & 32 \\
\hline $234 v$ & 39 & 28 & 22 & -- & -- \\
\hline${ }^{230} \mathrm{Th}$ & 45 & 44 & 22 & - & -- \\
\hline${ }^{226} \mathrm{Ra}$ & 28 & 28 & 26 & -- & -- \\
\hline $210_{\mathrm{Pb}}$ & 12 & 7.9 & 27 & 26 & 151 \\
\hline $210_{p o}$ & 32 & 35 & 22 & 21 & 91 \\
\hline $235 u$ & $<9$ & $<2$ & 1 & -- & -- \\
\hline${ }^{232} \mathrm{Th}$ & $<1$ & 3 & 0.4 & -- & -- \\
\hline${ }^{228} \mathrm{Ra}$ & $<1$ & 1.1 & 1 & -- & -- \\
\hline
\end{tabular}




\subsection{WET PROCESS PHOSPHORIC ACID AND FERTILIZER PROOUCTION}

The wet process plants in Idaho typically have handled 2 to 2.5 million tons per year of high-grade ore. With the shutdown of the Beker Industries plant, about 1 to 1.5 million tons per year are now being processed. Primary products and byproducts from the wet process plants are phosphoric acid, various fertilizers made from phosphoric acid, and phosphogypsum.

\subsubsection{Process Description}

The following description is based on the J. R. Simplot Co. fertilizer complex near Pocatello (Figure 3.1) and comes primarily from a 1975 radiological survey conducted by the EPA (Eadie, Bernhardt, and Boysen 1978). Additional information on wet process plants in general and the J. R. Simplot Co. complex in particular was obtained from other sources (Smith 1982; PEDCo 1983; EPA 1973; Guimond and Windham 1975a,b).

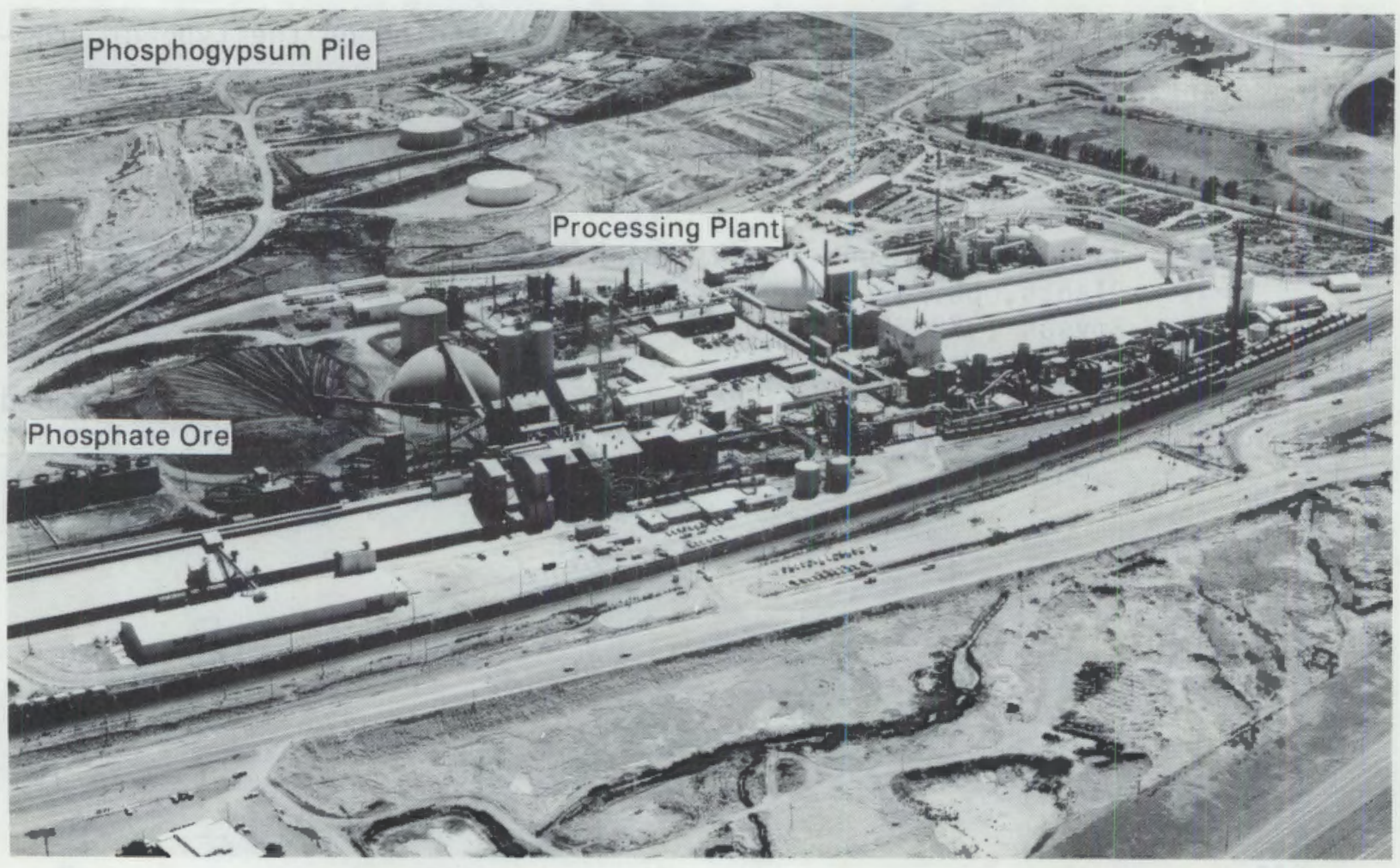

FIGURE 3.1. Aerial View of the J. R. Simplot Co. Wet Process Fertilizer Complex Near Pocatello 
At the J.R. Simplot Co. complex, phosphate rock is stockpiled onsite and then fed to a fluid bed calciner where it is heated to about $1400^{\circ} \mathrm{F}\left(760^{\circ} \mathrm{C}\right)$ to burn off the organic material. Gas from the calciner is scrubbed before being vented through a stack to the atmosphere. The calcining also upgrades the ore to approximately $32 \%$ to $34 \% \mathrm{P}_{2} \mathrm{O}_{5}$. The calcined ore is ground to a fine powder, which is fed to the phosphoric acid plant. Air from the grinding mill is vented to the atmosphere through a dust collector and a stack.

Ground phosphate rock is mixed with sulfuric acid in a reactor vessel to produce phosphoric acid and calcium sulfate (phosphogypsum). The reaction is approximated by the following equation:

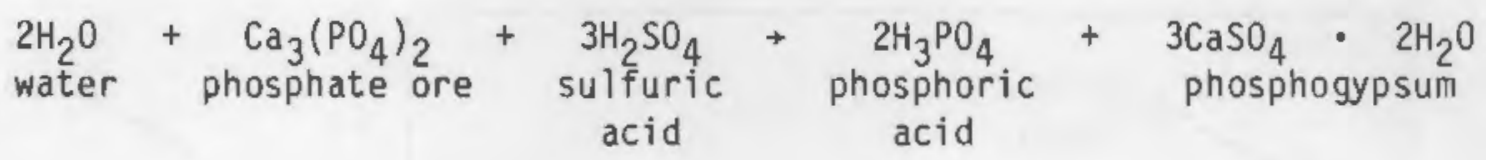

Phosphoric acid is separated from the phosphogypsum in a pan filter. Fumes from the exothermic reaction are collected and treated with water scrubbers. Phosphogypsum in the pan filters is rinsed and eventually pumped to a phosphogypsum pile. Water from the phosphogypsum pile is returned to the phosphoric acid circuit as process makeup water.

The phosphoric acid is used as the basis for several fertilizer formulations. The J.R. Simplot Co. uses it to produce three types of fertilizers: three grades of solid ammonium phosphate, two grades of liquid ammonium phosphate, and triple superphosphate (TSP). Ammonium sulfate is also made at the plant, but phosphoric acid is not used. To make solid ammonium phosphate, ammonia, phosphoric acid, and sulfuric acid are mixed in a reactor, granulated, and dried. Liquid fertilizer is made by reacting ammonia, water, and "super acid" $\left(70 \% \mathrm{P}_{2} \mathrm{O}_{5}\right)$ to form the liquid products. The TSP is made by reacting phosphate rock with phosphoric acid. The resulting material is granulated and dried. Off-gas from the dryer is scrubbed and vented through a stack.

\subsubsection{Radionuclide Pathways to the Environment}

Radionuclides contained in phosphate ore and wet process products can enter the environment through a number of pathways. Figure 3.2 shows potential radionuclide pathways to the environment for a wet process plant. 


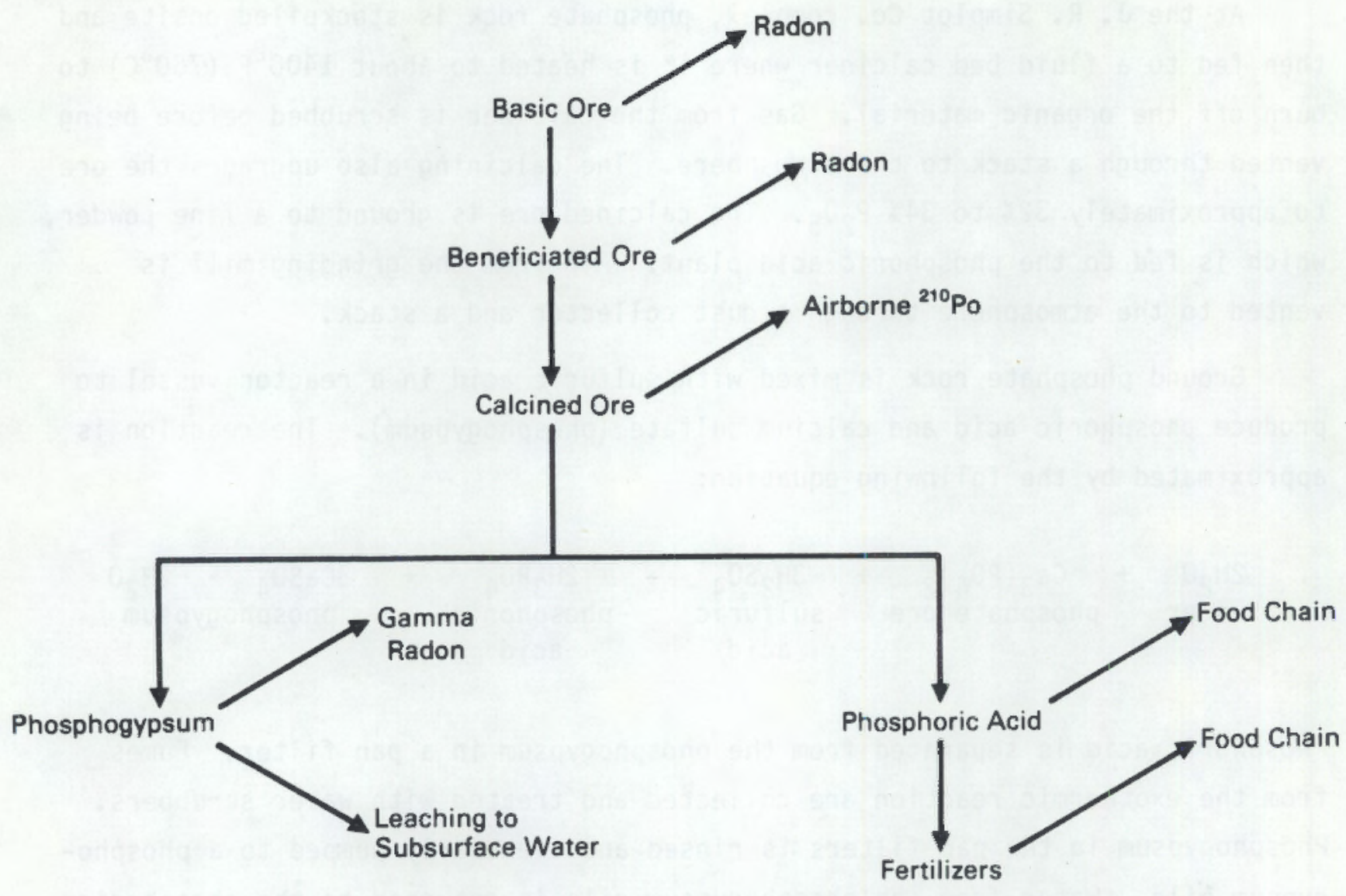

FIGURE 3.2. Radionuclide Pathways to the Environment for a Wet Process Plant (Booth 1977)

Both the ore and the phosphogypsum stored onsite may release ${ }^{222} \mathrm{Rn}$, a gaseous progeny of ${ }^{238} \mathrm{U}$. Furthermore, during production of phosphoric acid or fertilizer, volatile radionuclide such as ${ }^{210} \mathrm{Po},{ }^{210} \mathrm{~Pb}$, and ${ }^{22} 2_{\mathrm{Rn}}$ may be emitted in the calcines off-gas. Also, the fertilizer products themselves contain trace quantities of radioactive materials, primarily uranium, which can enter the environment. The main byproduct is phosphogypsum, which contains radium, a source of radon and gamma radiation and a potentially reachable contaminant to subsurface waters (Booth 1977). Similarly, ore stockpiles are a source of ${ }^{222} \mathrm{Rn}$ and fugitive dust containing radionuclides. The radiological survey of the J. R. Simplot Co. complex identified another significant source of airborne radionuclide to be the TSP dryer stack.

3.4 


\section{Airborne Radionuclides}

Sources of airborne radionuclides are the TSP dryer, the calciners and other stack emissions, and fugitive emissions from ore stockpiles and phosphogypsum piles. There are three fluid bed calciners at the J. R. Simplot Co. complex and two at the Beker Industries plant. The sizes of the calciners and particulate control and emission data from these plants are given in Table 3.2.

In elemental phosphorus plants, the particulate emissions from the calciners contain significant quantities of $210 P_{0}$ and $210 \mathrm{~Pb}$, which are volatilized in the calciner and condensed on particulate matter (see Table 3.9). However, calciners at wet process plants operate at lower temperatures, and recent EPA tests at the J.R. Simplot Co. plant showed that relatively little volatilization of these radionuclides occurred during calcining (EPA 1987). Particulates in the calciner scrubber outlet were only slightiy enriched in 210 po. Polonium-210 concentrations in the particulates were 65 to $103 \mathrm{pCi} / \mathrm{g}$ compared with 11,000 to $37,000 \mathrm{pCi} / \mathrm{g}$ in particulates emitted from elemental phosphorus plant calciners (see Table 3.9).

The measured radionuclide enission rates were $0.06 \mu \mathrm{Ci} / \mathrm{h}$ for $210 \mathrm{~Pb}$ and $0.15 \mu \mathrm{Ci} / \mathrm{h}$ for ${ }^{210} \mathrm{po}_{0}$. The estimated annual emission rates for the calciner tested were $0.5 \mathrm{mCi} /$ year for $210_{\mathrm{Pb}}$ and $1 \mathrm{mCi} /$ year for ${ }^{210} \mathrm{Po}$. These radionuclide emission rates are based on a particulate emission rate of $1.6 \mathrm{~kg} / \mathrm{h}$ measured during the test. This measurement corresponds to a particulate removal efficiency of $99.7 \%$ and a 210 po removal efficiency of $99.6 \%$. Particulate emission rates that were an order of magnitude higher have been reported for the J. R. Simplot Co. plant as shown in Table 3.2 (Smith 1982). Even with an order of magnitude increase, ${ }^{210}$ po enissions from the wet process would still be several orders of magnitude lower than the proposed standard of $21 \mathrm{Ci} /$ year. 
TABLE 3.2. Particulate Emissions from Phosphate Rock Calciners at Wet Process Plants (Smith 1982)

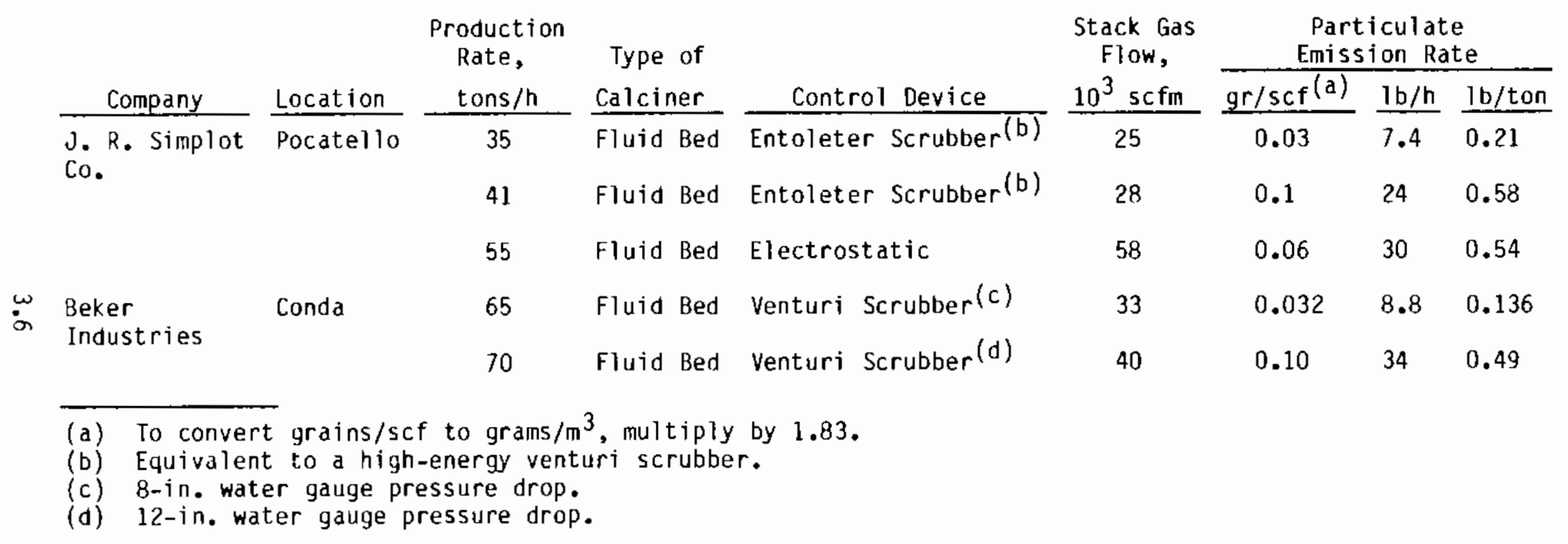


The 1975 EPA survey (Eadie, Bernhardt, and Boysen 1978) found that the TSP dryer stack was the largest source of airborne radionuclide emissions. The concentration of radionuclides $\left(238 \mathrm{U}\right.$ chain) was about $10 \mathrm{pCi} / \mathrm{m}^{3}$. Other stacks sampled during the EPA survey were the phosphoric acid scrubber, the grinding mill stack, and the ammonium phosphate reactor stack. Radionuclide concentrations were at least an order of magnitude lower in these locations than those measured in the TSP stack. Eadie, Bernhardt, and Boysen (1978) estimated the total radionuclide emissions from the J. R. Simplot $\mathrm{C}_{0}$. plant to be about 5 to $10 \mathrm{mCi} /$ year of $210 \mathrm{~Pb}, 226_{\mathrm{Ra}}, 234 \mathrm{U}$, and ${ }^{238} \mathrm{U}$ with lower values for ${ }^{230} \mathrm{Th}$ and $210_{\text {po. }}$

The TSP process has been extensively modified since these data were taken, and emission of airborne radionuclides has been greatly reduced. Because this process was the major source of radionuclide emissions, the current total radionuclide emissions from the J. R. Simplot Co. plant should be much lower than those reported by Eadie, Bernhardt, and Boysen (1978).

\section{Phosphogypsum}

Phosphogypsum, a byproduct produced by the reaction of phosphate rock and sulfuric acid, is another source of radionuclide emissions to the environment.

Most of the ${ }^{226} \mathrm{Ra}$ in the rock is not dissolved by acidulation with sulfuric acid and remains with the phosphogypsum. Some of the uranium and the thorium does enter solution and is transferred to the phosphoric acid product (Guimond and Windham 1975a). Radionuclide concentrations for three phosphogypsum solid samples from Idaho phosphoric acid plants are shown in Table 3.3, along with a feed ore for comparison.

About 3 to 4 tons of phosphogypsum are produced per ton of $\mathrm{P}_{2} \mathrm{O}_{5}$ processed, or about 1 ton of phosphogypsum per ton of rock fed. Annual production of phosphogypsum in Idaho is estimated at 2 million tons per year with both plants operating. With the shutdown of the Beker Industries plant, production of phosphogypsum will drop to about 1 million tons per year.

Phosphogypsum slurry from the phosphoric acid plant is pumped to piles for storage. Characteristics of the phosphogypsum piles at the J.R. Simplot Co. and Beker Industries facilities are shown in Table 3.4. 
TABLE 3.3. Radionuclide Concentration in Phosphogypsum Solids, $\mathrm{pCi} / \mathrm{g}$

\begin{tabular}{|c|c|c|c|c|}
\hline \multirow[b]{2}{*}{ Radionuclide } & \multirow{2}{*}{$\begin{array}{l}\text { Calcined } \\
\text { Feed Ore } \\
\text { (a) }\end{array}$} & \multicolumn{3}{|c|}{ Phosphogypsum } \\
\hline & & (a) & (b) & (c) \\
\hline $238_{U}$ & 38 & $<14$ & - & -- \\
\hline $234 U$ & 64 & 24 & -- & -- \\
\hline${ }^{230} \mathrm{Th}$ & 65 & 26 & -- & -- \\
\hline $226_{R a}$ & 38 & 23 & 7.9 & 16 \\
\hline $210_{\mathrm{pb}}$ & 1 & 1.1 & -- & -- \\
\hline $210 p_{0}$ & 42 & 26 & -- & -- \\
\hline $235_{U}$ & 1 & $<6.8$ & -- & -- \\
\hline $232 \mathrm{Th}$ & 0.4 & $<1.3$ & -- & -- \\
\hline${ }^{228} \mathrm{Ra}$ & $<1$ & $<1.0$ & -- & -- \\
\hline
\end{tabular}

(a) Eadie, Bernhardt, and Boysen (1978).

(b) PEDCo (1983).

(c) EPA (1973).

TABLE 3.4. Phosphogypsum Piles in Idaho (PEI 1985)

\begin{tabular}{|c|c|c|c|c|c|}
\hline Company & Location & $\begin{array}{c}\text { Number } \\
\text { of Piles }\end{array}$ & $\begin{array}{l}\text { Size, ha } \\
\text { (acres) }\end{array}$ & $\begin{array}{l}\text { Height, m } \\
\text { (ft) }\end{array}$ & $\begin{array}{r}\text { Quantity, } \\
\text { metric tons } \\
\text { (short tons) }\end{array}$ \\
\hline Beker Industries & Conda & 1 & $\begin{array}{c}36 \\
(90)\end{array}$ & $\begin{array}{c}24 \\
(80)\end{array}$ & $\begin{array}{r}7.9 \times 10^{6} \\
\left(8.7 \times 10^{6}\right)\end{array}$ \\
\hline \multirow[t]{2}{*}{ J. R. Simplot Co. } & Pocatello & 2 & $\begin{array}{c}24 \\
(60)\end{array}$ & $\begin{array}{l}15 \\
(50)\end{array}$ & $\begin{array}{r}3.3 \times 10^{6} \\
\left(3.6 \times 10^{6}\right)\end{array}$ \\
\hline & & & $\begin{array}{c}81 \\
(200)\end{array}$ & $\begin{array}{c}18 \\
(60)\end{array}$ & $\left(\begin{array}{r}15.0 \times 10^{6} \\
\left(17.0 \times 10^{6}\right)\end{array}\right.$ \\
\hline
\end{tabular}

During the 1975 survey, EPA measured a net gamma exposure rate (gross gamma exposure minus background) of $31 \mathrm{jR} / \mathrm{h}$ or $52 \mathrm{mrem} / \mathrm{year}$ on the phosphogypsum pile at the J. R. Simplot Co. facility. This value was typical for the general work areas tested in the plant. A radon concentration of $0.31 \mathrm{pCi} / 1$ was measured on the phosphogypsum pile (Eadie, Bernhardt, and Boysen 1978).

More recent radon flux measurements and radon-in-air measurements on phosphogypsum piles have been made in Florida (Freeman and Hartley 1985; PEI 
1986). Radon was also measured in the air short distances from the piles (PEI 1986). Evaluation of these data may indicate the potential significance of radon exhalation from Idaho phosphogypsum piles.

\section{Wastewater}

Plant effluents are another potential source of radionuclide releases to the environment. At a wet process phosphoric acid plant, wastewater is generated from two main sources: scrubber liquids and water associated with the phosphogypsum byproduct. Table 3.5 shows the radionuclide concentrations for some water streans at the J. R. Simplot Co. plant. Suspended solids were allowed to settle out in some of the samples, and both the solid and liquid were analyzed.

Scrubber liquids are treated prior to discharge or recycled back to the process. The radionuclide content of the outfall from the J.R. Simplot Co. plant measured in 1973 and 1975 is shown in Table 3.6. The incoming well water for the plant is shown for comparison. There has been no outfal? from the plant since 1980.

\section{Fertilizer Products}

The radionuclide concentration in some phosphate fertilizers from the J. R. Simplot Co. complex is shown in Table 3.7, along with an analysis of ammonium sulfate for comparison. The ammonium phosphates made from phosphoric acid show elevated levels of $238_{U}$ and ${ }^{230}$ Th $\left({ }^{226} \mathrm{Ra}\right.$ remains primarily in the phosphogypsum). The TSP made from both phosphoric acid and phosphate rock shows elevated levels of ${ }^{226} \mathrm{Ra},{ }^{210} \mathrm{Po}$, and ${ }^{234} \mathrm{U}$, as well as ${ }^{238} \mathrm{U}$ and ${ }^{230} \mathrm{Th}$.

\subsubsection{Radionuclide Material Balance}

Sufficient data are not available to determine a radionuclide material balance for a wet process plant, although some generalizations can be made. Typical feed ore for the plant has a radionuclide activity of 30 to $40 \mathrm{pCi} / \mathrm{g}$ for ${ }^{238} \mathrm{U}$, with progeny usually close to equilibrium. This activity corresponds to 30 to $40 \mu \mathrm{Ci} /$ ton of feed ore. Most of the radium goes to the phosphogypsum byproduct, but some of the uranium and thorium end up in the phosphoric acid products. In a study of Florida ores, Guimond and Windham (1975a,b) indicate that ${ }^{238} U,{ }^{234} \mathrm{U}$, and ${ }^{230}$ Th are significantly dissolved by the sulfuric acid in 
TABLE 3.5. Radionuclide Content of Process Waters at Wet Process Phosphoric Acid Plant (Eadie, Bernhardt, and Boysen 1978)

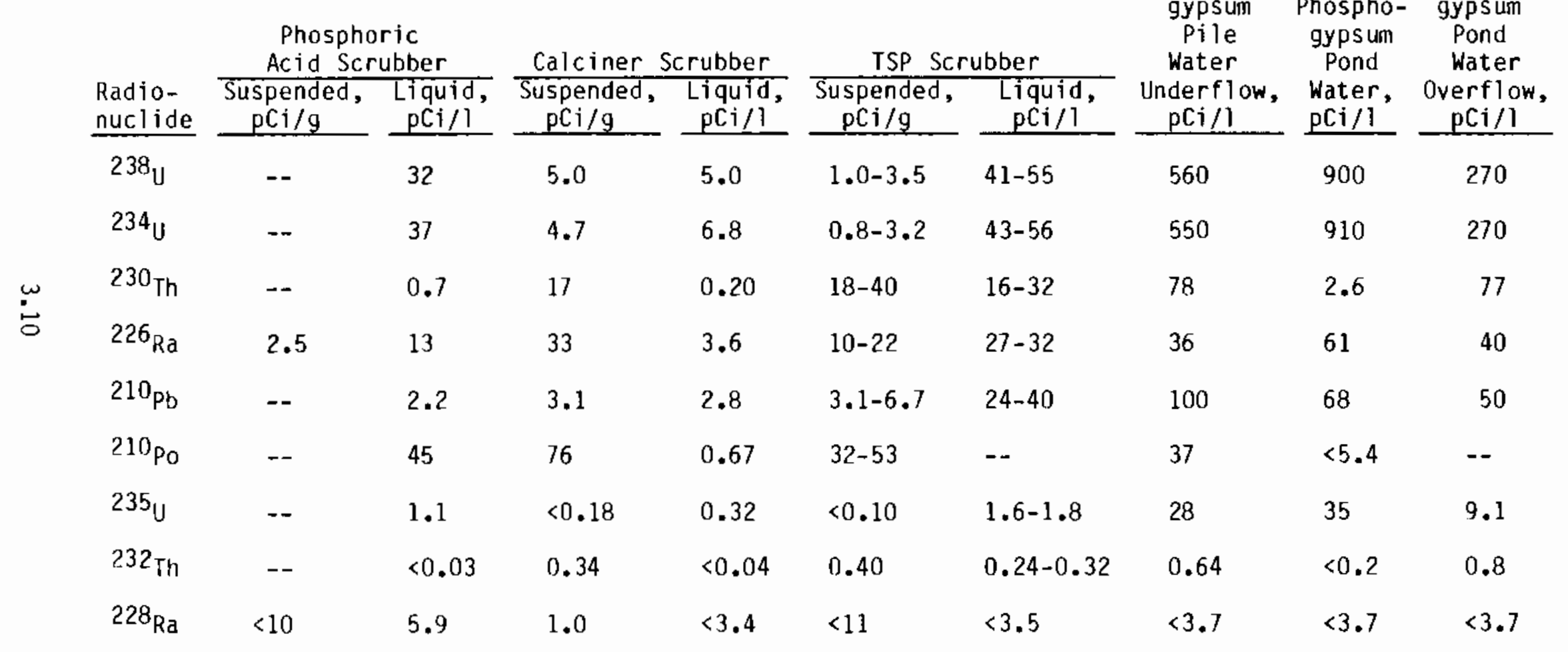


TABLE 3.6. Radionuclide Content of Outfall and Incoming Water at J. R. Simplot Co. Plant, pCi/l

Radjonuclide

$238_{\mathrm{U}}$

$234 \mathrm{U}$

$230 \mathrm{Th}$

$226_{\mathrm{Ra}}$

$210_{\mathrm{Pb}}$

$210_{\mathrm{p}}$

$235 \mathrm{U}$

$232 \mathrm{Th}$

${ }^{228} \mathrm{Ra}$

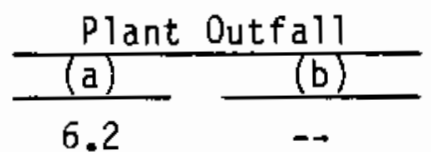

9.6

1.6

0.63

3.4

1.4

0.35

$<0.1$

4.0
Incoming

Well Water

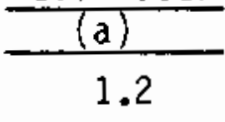

3.2

$<0.04$

0.7

1.2

$<0.8$

0.12

$<0.04$

$<3.7$

(a) Eadie, Bernhardt, and Boysen (1978).

(b) EPA (1973).

TABLE 3.7. Radionuclide Content of Fertilizer Products, $\mathrm{pCi} / \mathrm{g}$ (Eadie, Bernhardt, and Boysen 1978)

$\begin{array}{ccccc}\text { Radionuclide } & \begin{array}{c}\text { Ammonium } \\ \text { Phosphate } \\ \text { (various grades) }\end{array} & \begin{array}{c}\text { Triple Super- } \\ \text { phosphate }\end{array} & \begin{array}{c}\text { Ammonium } \\ \text { Sulfate }\end{array} \\ 238_{\mathrm{U}} & 21-27 & 44 & <1.2 \\ 230 \mathrm{Th} & <20 & 45 & <1.3 \\ 226_{\mathrm{Ra}} & 0.65-1.6 & 54 & <0.16 \\ 210_{\mathrm{Pb}} & 0.62-1.8 & 14 & 0.1 \\ 210_{\mathrm{Po}} & 2.1-4.6 & 3.6 & 1.3 \\ 235_{\mathrm{U}} & <13 & 18 & <0.47 \\ 232 \mathrm{Th} & 0.08-2.0 & <3.3 & <0.84 \\ 228_{\mathrm{Ra}} & <0.92-1.8 & <1.6 & <0.11\end{array}$


the phosphoric acid plant. About $50 \%$ to $80 \%$ of the thorium and $80 \%$ of the uranium is dissolved and ends up in the phosphoric acid products. A comparison of the radionuclide concentrations in the phosphogypsum and the calcined feed ore in Table 3.3 indicates that about $50 \%$ of the $238 \mathrm{U}, 234 \mathrm{U}$, and ${ }^{230} \mathrm{Th}$ is solubilized.

Some of the soluble radionuclides also end up in the phosphogypsum water, particularly $234 \mathrm{U}$ and $238 \mathrm{U}$. No information is available to determine what fraction of the total radioactivity is accounted for in the water stream. Very small quantities of radionuclides (about 5 to $10 \times 10^{-3} \mu \mathrm{Ci} /$ ton of feed ore) have been detected in the particulates in stack gases.

\subsection{THERMAL PROCESS FOR PRODUCTION OF ELEMENTAL PHOSPHORUS}

About 2 to 2.5 million tons per year of low-grade ore are processed in the two elemental phosphorus plants in Idaho. The primary product is elemental phosphorus. Phosphorus slag, an amorphous calcium silicate, is also produced and has been sold commercially as an aggregate.

\subsubsection{Process Description}

The Monsanto and FMC thermal process plants (Figures 3.3 and 3.4 ) are similar in design and operation (EPA 1984b,C; Gallaghar 1976; Eadie and Bernhardt 1977). At the FMC plant, phosphate rock is crushed, screened, and formed into briquettes before being fed to two moving-grate calciners. At the Monsanto plant, phosphate rock is fed directly to a rotary kiln calciner.

In both plants, rock (or briquettes) is heated to $1200^{\circ} \mathrm{C}$ to $1300^{\circ} \mathrm{C}$ in the calciners to remove organic materials and to form heat-hardened nodules that will withstand further processing without disintegrating. The nodules are cooled and passed through a proportioning building where they are blended with sized coke and silica before being fed into an electric arc reducing furnace. High-temperature reactions in the furnace $\left(2500^{\circ} \mathrm{C}\right) \mathrm{drive}$ off gaseous phosphorus and carbon monoxide and leave molten residues of slag and ferrophosphorus. Furnace off-gases pass through electrostatic precipitators to remove dust before entering a condenser, where phosphorus is condensed, collected in a sump, and pumped to storage. 


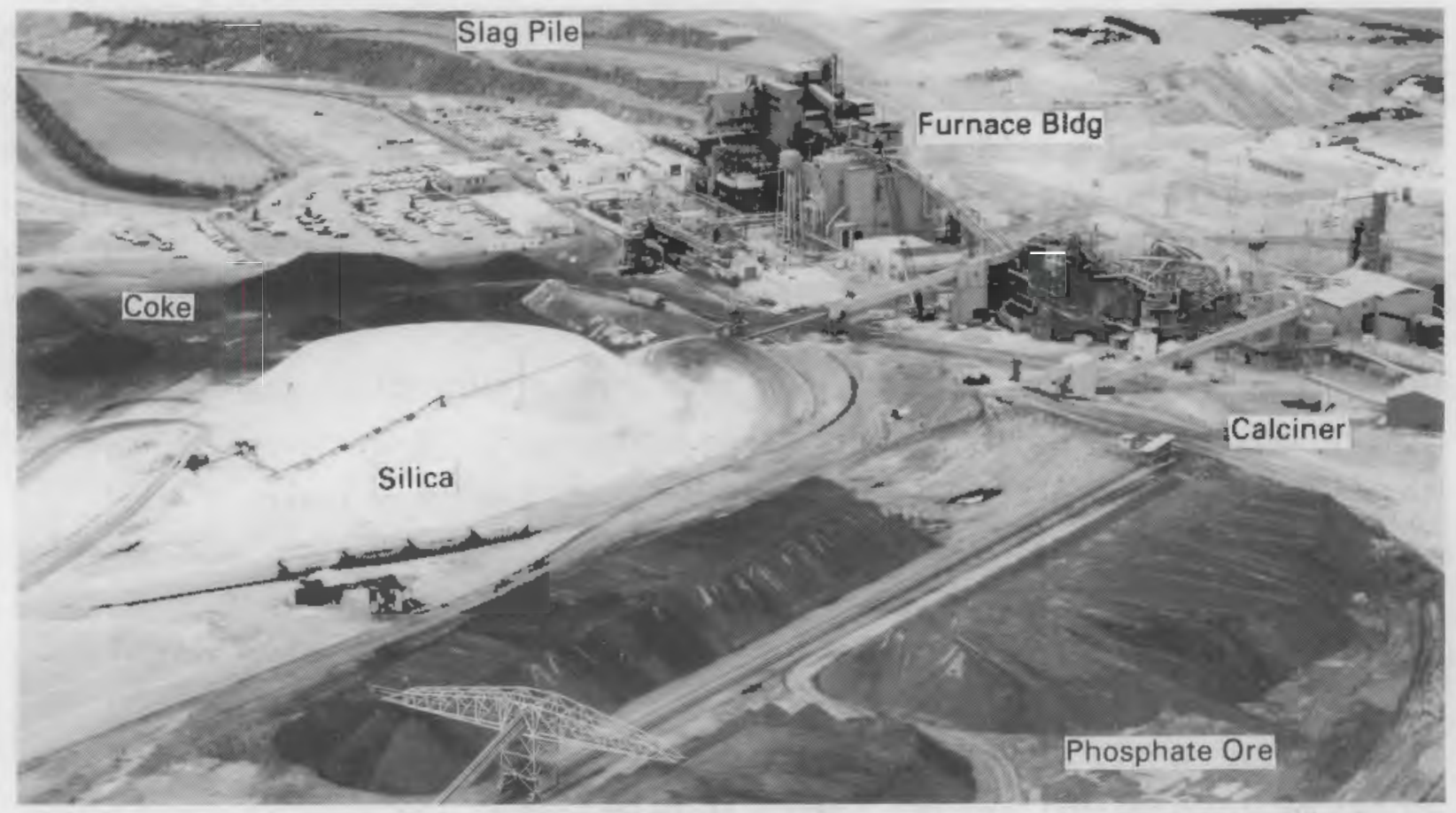

\section{FIGURE 3.3. Monsanto Elemental Phosphorus Plant Near Soda Springs}

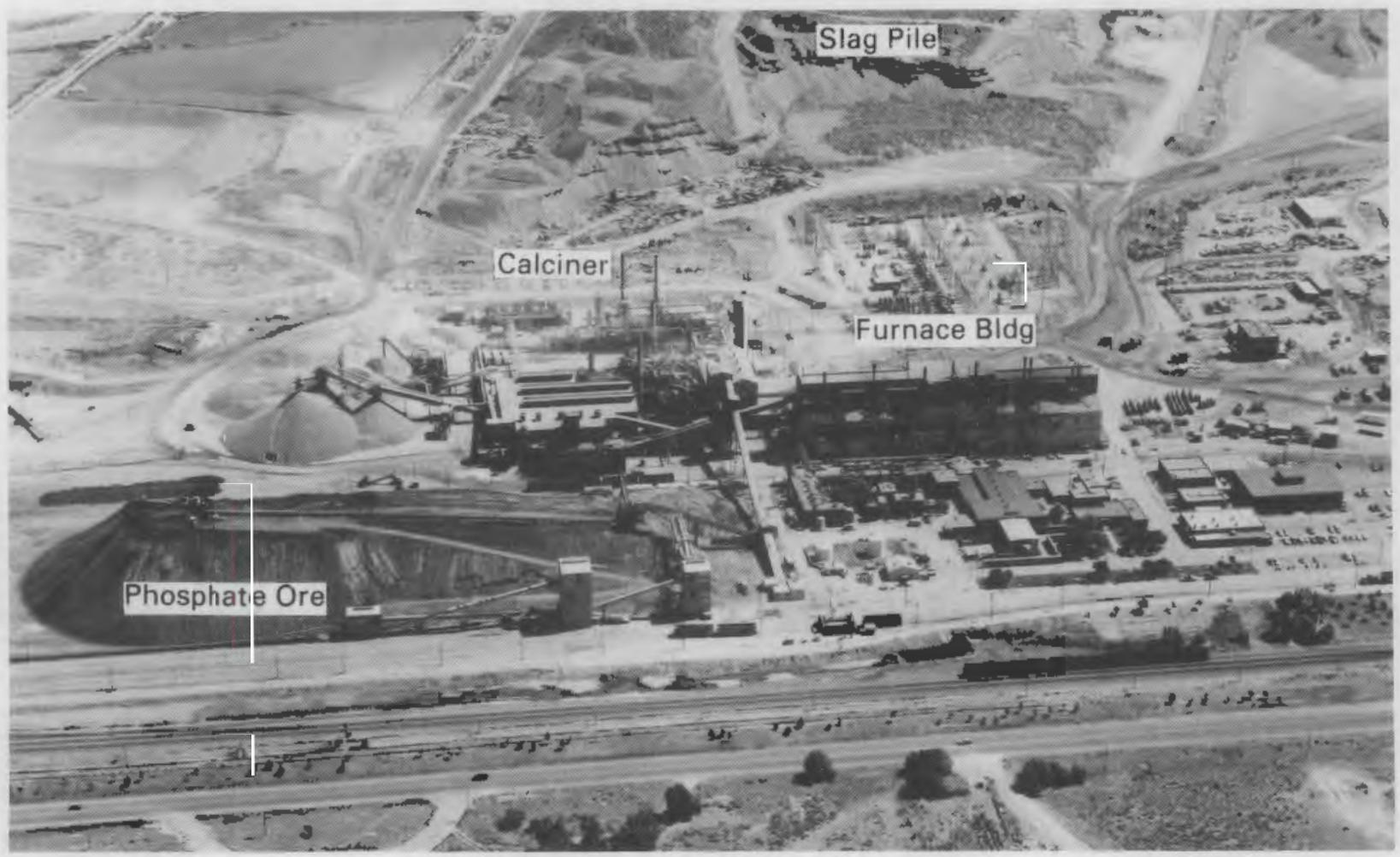

FIGURE 3.4. FMC Elemental Phosphorus Plant Near Pocatello 
Cleanup of the calciner off-gases is different for each plant. At the FMC plant, exhaust gases pass sequentially through a fan, a spray quench chamber, a horizontal scrubber, a demister, a second fan, and out the stack. Two parallel gas-cleanup trains are used; one with chevron demisting pads, the other with a cyclonic demisting system. Water from the scrubber system is transported to a settling pond.

Off-gases from the Monsanto kiln pass through a settling chamber, a spray tower, and a demister prior to discharge to the air. Spray tower effluent goes to a settling pond, and the water is recycled to the spray tower.

\subsubsection{Radionuclide Pathways to the Environment}

Figure 3.5 shows the potential radionuclide pathways to the environment for an elemental phosphorus plant. The ore pile at the plant may emit ${ }^{222_{R n}}$ and fugitive dust. Because of higher calciner temperatures, radionuclide emissions from thermal process plant calciners are higher than from wet process plants. Volatile radionuclides, such as ${ }^{210} \mathrm{Po},{ }^{210} \mathrm{~Pb},{ }^{226} \mathrm{Ra}$ and ${ }^{230} \mathrm{Th}$, may be emitted in the calciner off-gas, along with ${ }^{222} \mathrm{Rn}$. Radionuclides also may be volatilized in the furnace.

Another potential pathway is the slag, which contains significant concentrations of radium. These concentrations may lead to gamma radiation exposures associated with use of slag, and potential radon/progeny exposures associated with its use as an aggregate in concrete for building construction.

\section{Calciner Off-Gases (and other airborne emissions)}

Emission tests of the calciner off-gases at the two Idaho elemental phosphorus plants have recently been completed (Jongleux 1984a,b; EPA 1984b,c). Comparison of the radionuclide content of the phosphate rock feedstock and the calcined product shown in Table 3.8 indicates that about $98 \%$ of the 210 po and about $95 \%$ of ${ }^{210} \mathrm{~Pb}$ are volatilized in the calciner at the Monsanto plant near Soda Springs. At the FMC plant near Pocatello, about $60 \%$ of the ${ }^{210}$ Po $_{0}$ is volatilized, while almost no ${ }^{210} \mathrm{~Pb}$ is volatilized. At both plants, very little or no ${ }^{238} \mathrm{U}$ is volatilized. Both calciners operate at similar temperatures $\left(1200^{\circ} \mathrm{C}\right.$ to $\left.1300^{\circ} \mathrm{C}\right)$. The reduced volatilization at the FMC plant is apparently 


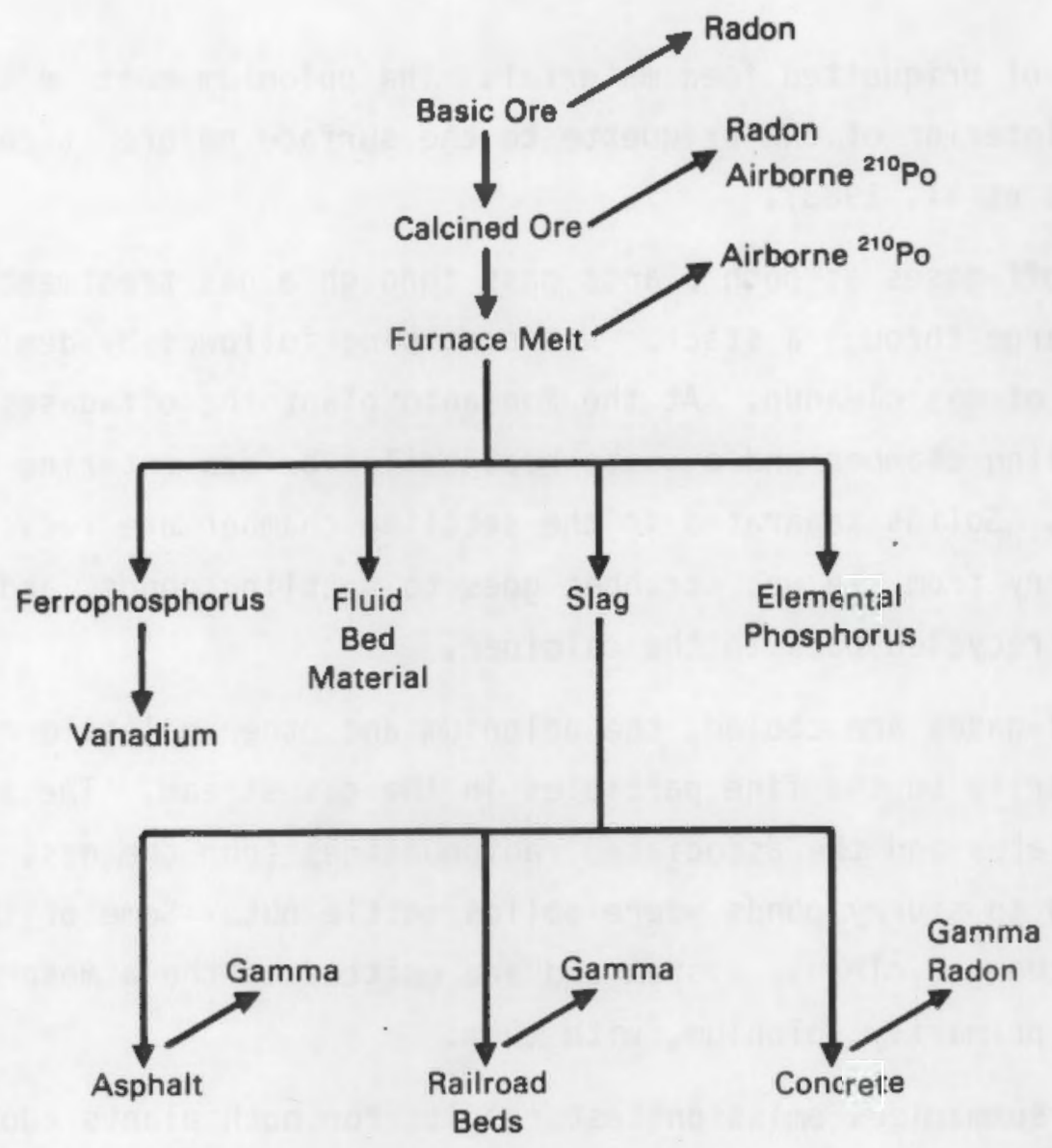

FIGURE 3.5. Radionuclide Pathways to the Environment for a Thermal Process Plant

TABLE 3.8. Radionuclide Content of Phosphate Rock Feedstock and Calcined Product at Idaho Elemental Phosphorus Plants (EPA 1984b,c)

\begin{tabular}{|c|c|c|c|}
\hline \multicolumn{2}{|c|}{ Radionuclide } & $\begin{array}{c}\text { Feedstock, } \\
\mathrm{pCi} / \mathrm{g} \\
\end{array}$ & $\begin{array}{l}\text { Calcined } \\
\text { Product, } \\
\mathrm{pCi} / \mathrm{g}\end{array}$ \\
\hline \multirow[t]{3}{*}{ Monsanto } & $238 U$ & 32 & 37 \\
\hline & $210 \mathrm{~Pb}$ & 150 & 6 \\
\hline & ${ }^{210} p_{0}$ & 91 & 2 \\
\hline \multirow[t]{3}{*}{ FMC } & $238_{U}$ & 21 & 22 \\
\hline & $210 \mathrm{~Pb}$ & 26 & 27 \\
\hline & ${ }^{210} \mathrm{PO}$ & 21 & 8 \\
\hline
\end{tabular}


due to the use of briquetted feed material. The polonium must be transported from the bulk interior of the briquette to the surface before it can be released (Stula et al. 1983).

Calciner off-gases at both plants pass through a gas treatment system prior to discharge through a stack. Wet scrubbing followed by demisting is the primary method of gas cleanup. At the Monsanto plant the off-gases pass through a settling chamber and a waste heat boiler before entering the gascleanup system. Solids separated in the settling chamber are recycled to the calciner. Slurry from the wet scrubber goes to settling ponds, and the solids are eventually recycled back to the calciner.

As the off-gases are cooled, the polonium and other volatile radionuclides condense, primarily on the fine particles in the gas stream. The scrubbers remove particulates and the associated radionuclides from the gas. Scrubber water is pumped to slurry ponds where solids settle out. Some of the fine particles escape the gas-cleanup system and are emitted to the atmosphere carrying radionuclides, primarily polonium, with them.

Table 3.9 summarizes emission test results for both plants (Jongleux 1984a,b; EPA 1984b,c). Estimated yearly radionuclide emissions from the calciner stack for the Monsanto plant are $21 \mathrm{Ci}$ of $210 \mathrm{Po}$ and $5.6 \mathrm{Ci}$ of $210 \mathrm{pb}$. For the FMC plant, estimated yearly radionuclide emissions are $9 \mathrm{Ci}$ of $210 \mathrm{po}$ and $0.1 \mathrm{Ci}$ of $210 \mathrm{~Pb}$. Also included in Table 3.9 are recent results obtained by Monsanto and FMC, which show totals of 20.8 and $6.7 \mathrm{Ci} /$ year of $210 \mathrm{Po}$, respectively. The FMC results were obtained by using EPA Method 5 and EPA Method III calculation procedure. The stack sampling procedure is described in detail by Buttelman (1986). Oetails on the Monsanto testing are not available.

As part of the tests by Jongleux $(1984 a, b)$ and EPA $(1984 b, c)$, samples taken of the inlet/outlet gas of one scrubber at the FMC plant indicated that $77 \%$ of the $210 \mathrm{po}$ and $85 \%$ of the $210 \mathrm{pb}$ were removed from the calciner off-gas. About $70 \%$ of the polonium discharged from the stack was associated with particles smaller than $0.5 \mu \mathrm{m}$. At the Monsanto plant, about $95 \%$ each of the $210 \mathrm{po}_{0}$ and the $210 \mathrm{pb}$ was associated with particles smaller than $1 \mu \mathrm{m}$. 
TABLE 3.9. Airborne Emissions from Phosphate Rock Calciners at Elemental Phosphorus Plants (Jongleux 1984a,b; EPA 1984b,c)

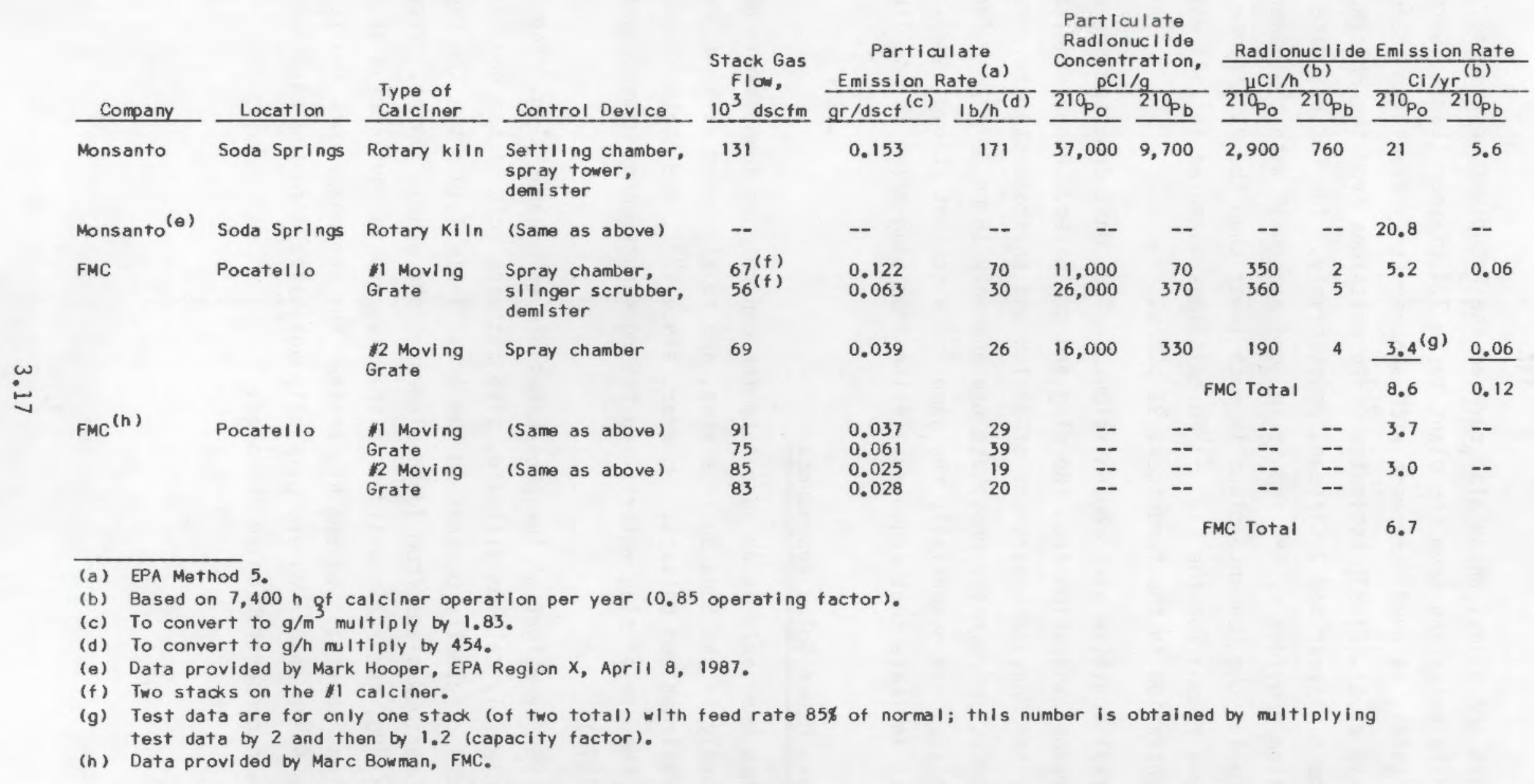


The 1975 EPA study, which also covered the FMC plant, estimated the total airborne 210 po emissions from the plant to be $7.4 \mathrm{Ci} /$ year (Eadie, Bernhardt, and Boysen 1978), in good agreement with another study (Eadie and Bernhardt 1977). Stula et al. (1983) estimated 210 Po emissions from the FMC and Monsanto plants to be $8 \mathrm{Ci} /$ year and $3 \mathrm{Ci} /$ year, respectively. The FMC estimate is based on information provided by FMC and is in good agreement with the other tests. The estimate for the Monsanto plant is much lower than the $21 \mathrm{Ci}$ year measured in 1984. One reason for the high 210 Po emissions measured in 1984 was the high 210 po concentration in the feedstock, $91 \mathrm{pCi} / \mathrm{g}$.

Potential fugitive airborne emissions include dust from the ore and slag piles and radon exhalation from the slag and ore piles. Radon exhalation rates measured by the Montana Department of Health and Environmental Sciences were 3400 to $3800 \mathrm{pCi} / \mathrm{m}^{2} / \mathrm{min}$ for phosphate ore and only 18 to $30 / \mathrm{m}^{2} / \mathrm{min}$ for slag even though they had essentially the same ${ }^{226} \mathrm{Ra}$ content (Lloyd 1983). These measurements indicate that radon exhalation from slag piles is not likely to be a problem.

Slag and Other Solid Byproducts

Slag has been sold as an aggregate for concrete in foundations of buildings, primarily in the Soda Springs area, and is also used as an aggregate for roads and railroad bed ballast. However, since 1977, the State of Idaho has prohibited the use of slag material in the construction of habitable structures (Peterson 1979).

About $85 \%$ by weight of the phosphorus ore ends up as slag. The slag, which is primarily calcium silicate, also contains most of the nonvolatile radionuclides originally present in the ore. Table 3.10 shows the radionuclide content of various slags from Idaho elemental phosphorus plants. Except for $210 \mathrm{po}$ and $210 \mathrm{pb}$, the radionuclides in the slag are in equilibrium at concentrations about $15 \%$ to $20 \%$ higher than the phosphate rock fed to the plant. The $210 \mathrm{po}$ and $210 \mathrm{pb}$ are partially volatilized in the calciner, which reduces their concentration in the slag. 
TABLE 3.10. Concentration of Radionuclides in Slags from Idaho

\begin{tabular}{|c|c|c|c|c|c|}
\hline \multirow[b]{2}{*}{ Radionuclide } & \multicolumn{5}{|c|}{ Concentration, $\mathrm{pCi} / \mathrm{g}$} \\
\hline & (a) & (b) & (c) & (c) & (d) \\
\hline $238_{U}$ & 25 & -- & & & 29 \\
\hline $234_{U}$ & 25 & -- & & & 38 \\
\hline${ }^{230} \mathrm{Th}$ & 26 & -- & & & 42 \\
\hline${ }^{226} \mathrm{Ra}$ & 32 & 15.2 & 39 & 41 & 50 \\
\hline $210_{\mathrm{Pb}}$ & 11 & -- & & & -- \\
\hline $210 \mathrm{po}_{0}$ & $<16$ & -- & & & -- \\
\hline${ }^{232} \mathrm{Th}$ & 0.6 & - & & & 0.5 \\
\hline${ }^{228} \mathrm{Ra}$ & 0.96 & -- & & & - \\
\hline
\end{tabular}
(a) Eadie and Bernhardt (1977).
(b) PEDCo (1983).
(c) Boothe (1977).
(d) Hans et al. (1978).

About 1.8 to 2.3 million tons of slag are produced by the two plants each year. The slag is stockpiled on the plant sites in Pocatello and Soda Springs (Boothe 1977; Melville 1980; Peterson 1979; Gallaghar 1976). Because of the low moisture conditions associated with the slag, no seepage collection systems are utilized.

Another solid byproduct from the elemental phosphorus plant is the dust removed from the electrostatic precipitators. This material is dried in a fluidized bed dryer, and the dried solids are referred to as "fluid bed prills." The fluid bed prills contain a high concentration of radionuclides that were volatilized in the furnace. Reported concentrations of radionuclides are 440 to $1550 \mathrm{pCi} / \mathrm{g} 210 \mathrm{po}, 52 \mathrm{pCi} / \mathrm{g} 210 \mathrm{pb}$, and 10 to $13 \mathrm{pCi} / \mathrm{g}{ }^{226} \mathrm{Ra}$ (Eadie and Bernhardt 1977; Gallaghar 1976). Using a production rate of 0.13 tons per ton of product, PEDCo (1983) estimated that 30,000 tons of fluid bed prills are produced in Idaho each year and stored on the plant sites.

A third solid byproduct is ferrophosphorus, the dense metallic material tapped from the bottom of the furnace. Ferrophosphorus from Monsanto is sold to the Kerr-McGee Corporation, which extracts the vanadium from it at a plant 
in Soda Springs. The FMC plant is currently stockpiling its ferrophosphorus. The radioactivity in the ferrophosphorus, about 30 to $50 \mathrm{pCi} / \mathrm{g}$, is primarily from ${ }^{234} \mathrm{U}$ and ${ }^{238} \mathrm{U}$ (Eadie and Bernhardt 1977; Gallaghar 1976).

Wastewater

Only limited information on wastewater streams from elemental phosphorus plants is available (Eadie and Bernhardt 1977; Gallaghar 1976; PEDCo 1983). The calciner scrubber liquid, the phosphorus condenser wastewater, and the fluid bed scrubber liquor are pumped to waste ponds onsite to separate the solids from the stream. These streams show some elevated radioactivity, but no contamination of the local environment by water from the elemental phosphorus plants has been observed.

\subsubsection{Radionuclide Material Balance}

Figure 3.6 shows an estimate of a radionuclide material balance for a thermal process plant, assuming a feed ore with a ${ }^{238} \mathrm{U}$ concentration of $30 \mathrm{pCi} / \mathrm{g}$ and progeny nuclides in equilibrium. The results are based on data from the FMC plant (Eadie and Bernhardt 1977; Gallaghar 1976; Stula et al. 1983). The majority of the radionuclides end up in the slag. A significant fraction of the ${ }^{210} \mathrm{po}$ and some of the $210 \mathrm{~Pb}$ are volatilized. The volatilized radionuclides ultimately end up as airborne emissions released out the calciner stacks or in a slurry from the calciner gas treatinent system. The fluid bed prills contain the majority of radionuclides volatilized in the furnace. Little or no radioactivity has been reported in the elemental phosphorus.

Based on an estimated feed rate of 1.2 million tons per year of ore at the FMC plant, about $35 \mathrm{Ci} /$ year of 210 po are charged to the plant. About 6 to $10 \mathrm{Ci} /$ year are discharged to the atmosphere from the calciner stack. The rest is distributed as indicated in Figure 3.6 .

The limited data available for the Monsanto plant makes a radionuclide material balance impossible at this time. The $210 \mathrm{po}$ and $210 \mathrm{pb}$ activity in the feedstock used during the recent tests is quite high and not in equilibrium (see Table 3.8 ). This is unusual because most phosphate ores show progeny nuclides to be in equilibrium with ${ }^{238} \mathrm{U}$. The high ${ }^{210_{\mathrm{Pb}}}$ and ${ }^{210} \mathrm{Po}$ content is 


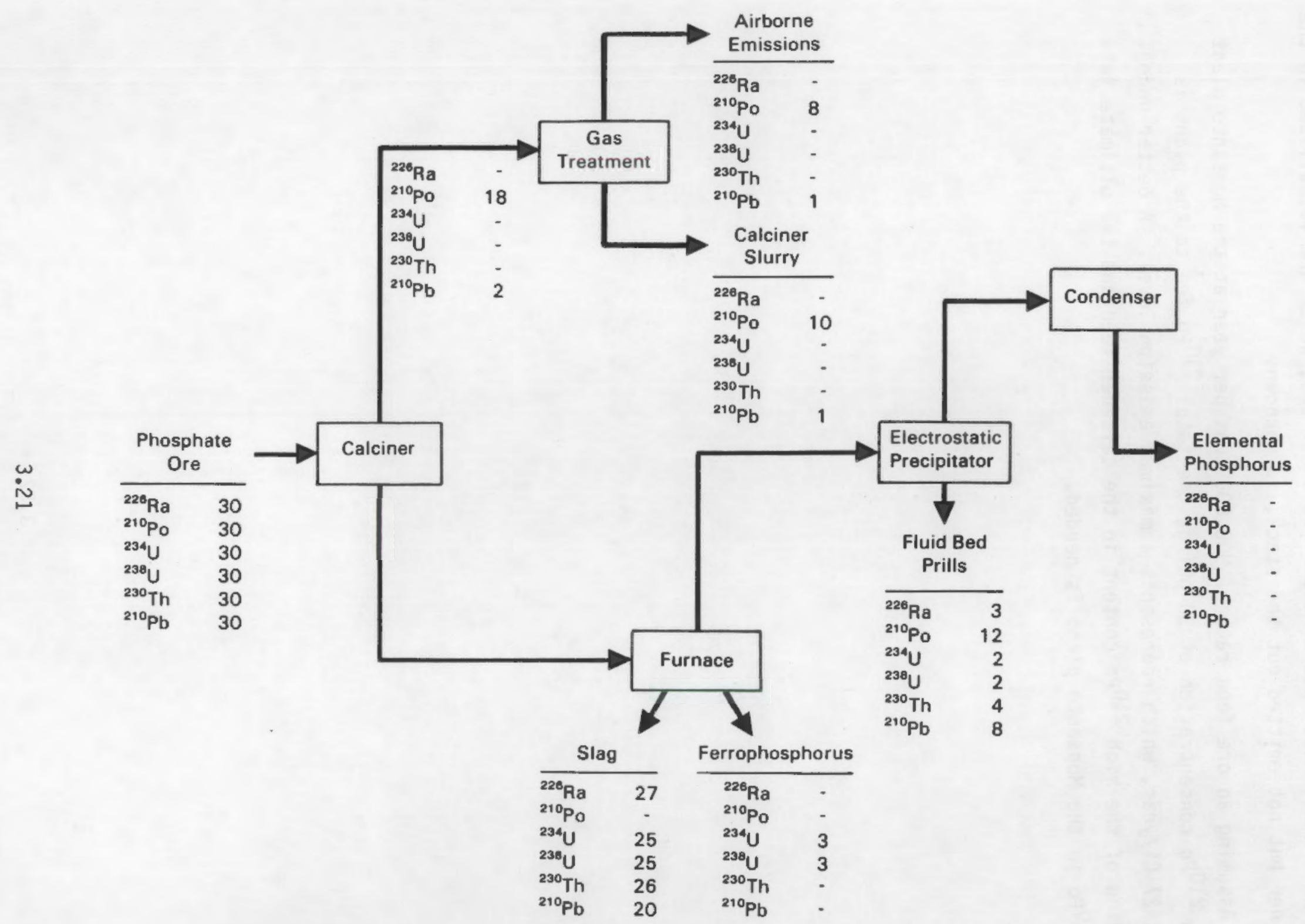

FIGURE 3.6. Radionuclide Material Balance for a Thermal Process Plant, PCi/g 
apparently due to recycling the settling chamber dust and the calciner scrubber solids. The ultimate fate of the ${ }^{210} \mathrm{po}_{\mathrm{o}}$ and $210 \mathrm{pb}$, which are volatilized in the calciner but not emitted out the stack, is unknown.

Assuming an ore feed rate of 900,000 tons per year at the Monsanto plant and a ${ }^{210} \mathrm{Po}_{0}$ concentration of $30 \mathrm{pCi} / \mathrm{g}$, the total $210 \mathrm{Po}$ fed to the plant is about $27 \mathrm{Ci} /$ year, which represents a maximum emission level. A better understanding of the high 210 po content in the calciner feed and the ultimate fate of $210 \mathrm{po}$ in the Monsanto plant is needed. 


\subsection{ENVIRONMENTAL RADIOACTIVITY FROM PHOSPHATE PROCESSING PLANTS}

Two major pathways by which radionuclides from phosphate processing plants are distributed within the environment are 1) radioactive particulates and radon gas emitted from stacks or from fugitive emissions from ore, slag, and phosphogypsum piles or 2) commercial use of byproducts such as slag or phosphogypsum. A third potential pathway has been theorized: contamination of ground or surface waters from plant discharges or leaching of waste ponds.

\subsection{AIRBORNE RADIONUCLIDES}

Elevated ${ }^{210}$ Po concentrations and alpha activity have been detected in the Pocatello area as an apparent result of phosphate processing operations. Figure 4.1 compares gross alpha air concentrations at three locations in Idaho measured in 1974 by the Health Services Laboratory, Idaho Operations Office, U.S. Department of Energy. The bottom curve is at a location (Howe) removed from all industrial activity and can be considered background. The top curve is for the Pocatello Sewage Treatment Plant located 0.5 mile downwind from the two phosphate processing plants (location A in Figure 4.2). The middle curve is for a location 15 miles downind from these plants near Blackfoot (Boothe 1977).

In an earlier study conducted by the U.S. Atomic Energy Commission (AEC 1970), the average gross alpha concentration in the air was $0.034 \mathrm{pCi} / \mathrm{m}^{3}$ at the Pocatello Sewage Treatment $\mathrm{Pl}$ ant and $0.0087 \mathrm{pCi} / \mathrm{m}^{3}$ at the Pocatello Fire Station during a 6-month period in 1969-1970. These concentrations compare with a background of $0.0016 \mathrm{pCi} / \mathrm{m}^{3}$. The study determined that most of the elevated alpha activity at the Pocatello Sewage Treatment Plant was ${ }^{210}$ Po. The ${ }^{210} \mathrm{Po}_{0}$ concentrations averaged $88 \%$ of the gross alpha activity.

Another study (Eadie and Lambdin 1980) found that airborne concentrations of ${ }^{234} \mathrm{U},{ }^{238} \mathrm{U},{ }^{226} \mathrm{Ra}$, and ${ }^{230} \mathrm{Th}$ at the Pocatello Sewage Plant were higher than at other sites near Pocatello and were about an order of magnitude greater than levels measured at Howe, the "background location." The other sites (B, C, D, and E) in Figure 4.2 were at least 3 miles from the phosphate plants and not in the predominant downwind direction. Concentrations at these sites are similar 


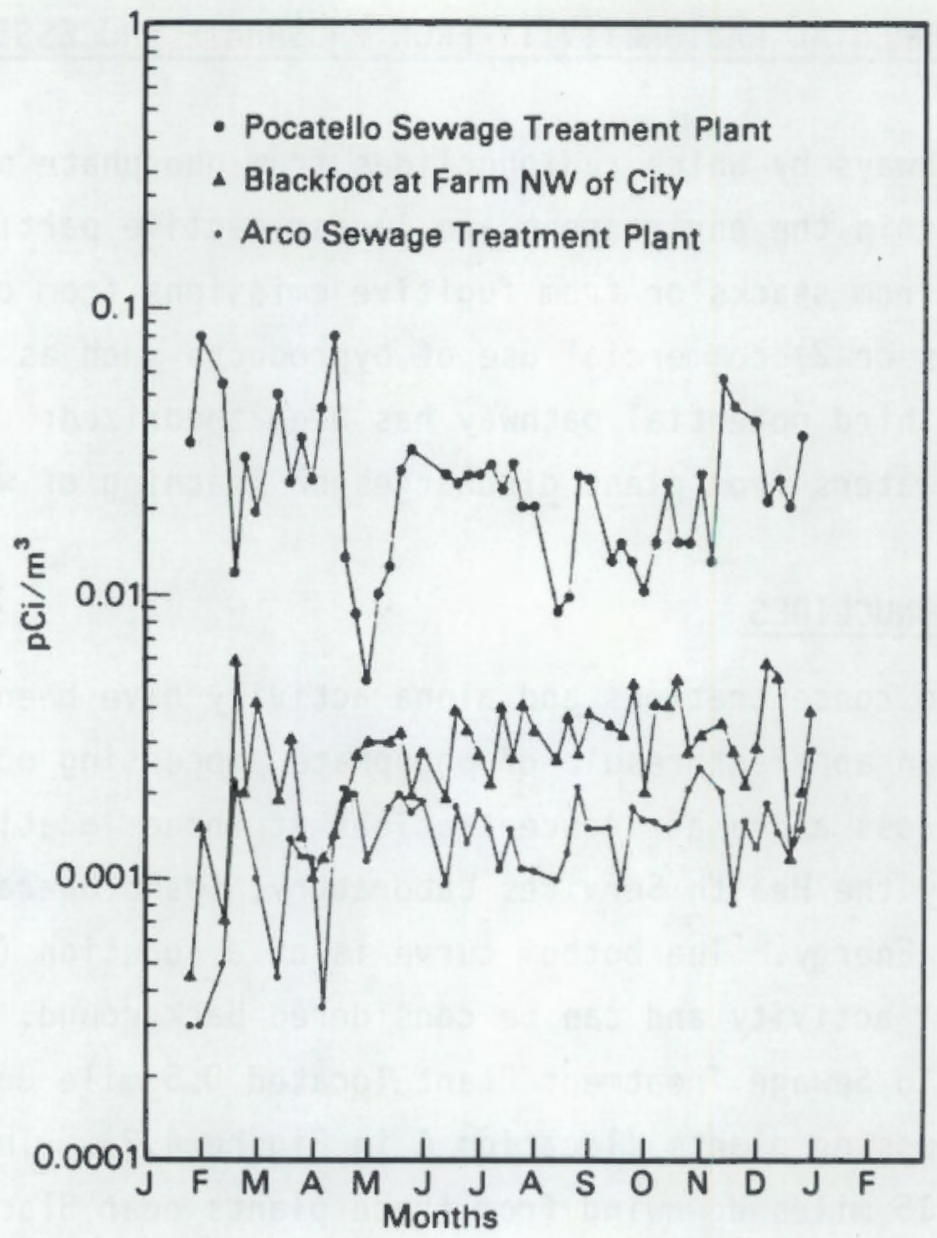

FIGURE 4.1. Gross Alpha Air Concentrations, 1974 (Boothe 1977)

to background levels reported for Chicago and New York but a factor of 3 higher than measured at Howe. Average annual lung dose in mrem/year for these sites is shown in Table 4.1. The ${ }^{210} \mathrm{Po}$ and $210 \mathrm{~Pb}$ concentrations were not reported because of technical difficulties encountered during the study; however, the authors concluded that these two radionuclides would be statistically above background.

Elevated ${ }^{210}$ Po levels have also been detected in soil in the Pocatello area (McNabb, Kirk, and Thompson 1979). Soil samples were collected at four locations (F, G, H, and I in Figure 4.2) in the vicinity of the phosphate processing plants where land appeared not to have been disturbed by 


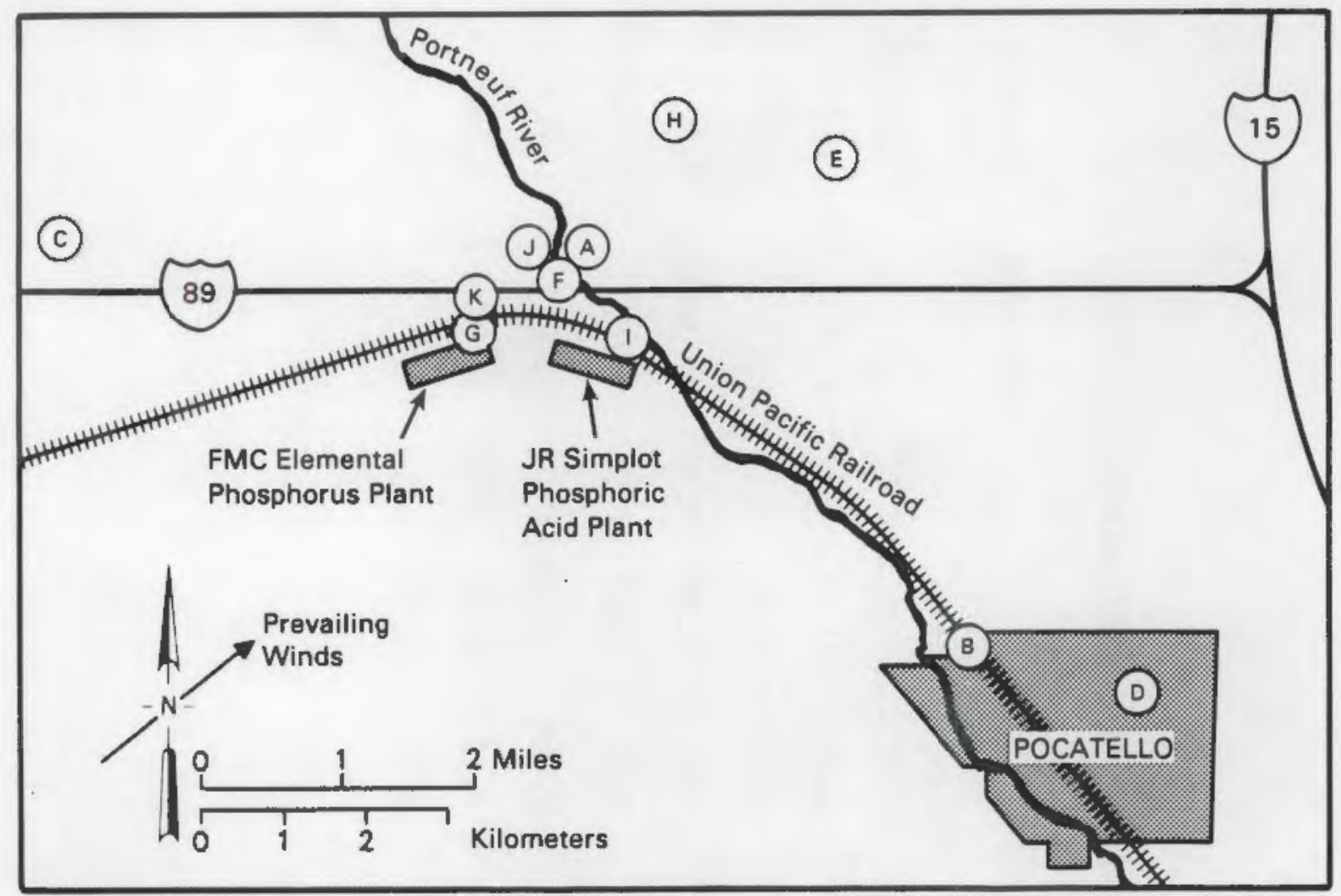

FIGURE 4.2. Sampling Locations in the Pocatello Area

industrial or farming activities. Subsurface samples contained ${ }^{238} U$ in equilibrium with its progeny, ${ }^{234} \mathrm{U},{ }^{230} \mathrm{Th}$, and ${ }^{210} \mathrm{po}_{\mathrm{o}}$, at about $1 \mathrm{pCi} / \mathrm{g}$ of sieved soil. Thorium-232 and its progeny, ${ }^{228} \mathrm{Th}$, were also in equilibrium at about 0.5 to $1.0 \mathrm{pCi} / \mathrm{g}$ depending on the site. Surface samples contained $238_{U}$ and progeny in concentrations significantly higher than the $1 \mathrm{pCi} / \mathrm{g}$ found in the subsurface soils, as shown in Table 4.2.

As indicated in Table 4.2 , the 210 po values exceeded the equilibrium with $238 \mathrm{y}$ at the first three sites, suggesting that the $210_{p_{0}}$ contamination came from the FMC calciner stack. The difference is most apparent at Site $G$, the closest site to the FMC elemental phosphorus plant. The high ${ }^{238} \mathrm{U}$ content shown for Location I may have resulted from blowing phosphate ore dust (McNabb, Kirk, and Thompson 1979).

In another study, ${ }^{210} p_{0}$ concentrations were determined for soil, vegetation, and deer mouse tissues collected at a solid radioactive waste disposal facility near Idaho Falls, near the phosphate plants at Pocatello, and at two 
TABLE 4.1. Average Annual Lung Dose (mrem/yr) for Insoluble Radionuclides (Eadie and Lambdin 1980)

\begin{tabular}{|c|c|c|c|c|c|c|c|c|c|}
\hline Radionuclide & $\begin{array}{c}\text { A } \\
\text { Sewage } \\
\text { Plant } \\
\end{array}$ & $\begin{array}{c}\text { B } \\
\text { Hayes Fire } \\
\text { Station } \\
\end{array}$ & $\begin{array}{c}C \\
\text { Airport } \\
\end{array}$ & $\begin{array}{c}\text { D } \\
\text { Courthouse } \\
\end{array}$ & $\begin{array}{c}\mathrm{E} \\
\begin{array}{c}\text { Chubbuck } \\
\text { School }\end{array} \\
\end{array}$ & $\begin{array}{l}\text { Howe, } \\
\text { Idaho } \\
\end{array}$ & $\begin{array}{l}\text { Arco, } \\
\text { Idaho }\end{array}$ & $\begin{array}{c}\text { New York } \\
\text { City } \\
\text { (NCRP } \\
1975 \text { ) } \\
\end{array}$ & $\begin{array}{r}\text { Argonne } \\
\text { National } \\
\text { Lab, Chicago } \\
\text { (NCRP 1975) }\end{array}$ \\
\hline $238_{u}$ & 1.8 & 0.32 & 0.32 & 0.29 & 0.58 & 0.10 & 0.17 & 0.08 & 0.38 \\
\hline${ }^{234} U$ & 2.3 & 0.37 & 0.41 & 0.41 & 0.63 & 0.12 & 0.23 & 0.93 & 0.44 \\
\hline${ }^{230} \mathrm{Th}$ & 3.0 & 0.54 & 0.48 & 0.48 & 0.82 & 0.24 & 0.31 & No data & 0.15 \\
\hline${ }^{226} \mathrm{Ra}$ & 2.7 & 1.0 & 0.56 & 1.7 & 1.8 & 0.28 & 0.26 & 0.37 & No data \\
\hline $235_{U}$ & 0.13 & 0.033 & 0.061 & 0.11 & 0.068 & 0.023 & 0.06 & 0.04 & 0.023 \\
\hline${ }^{232} \mathrm{Th}$ & 0.22 & 0.099 & 0.11 & 0.045 & 0.14 & 0.14 & 0.14 & No data & 0.090 \\
\hline $\begin{array}{r}\text { Total Dose } \\
\text { (mrem/yr) }\end{array}$ & 10 & 2.4 & 1.9 & 3.0 & 4.0 & 0.90 & 1.1 & 1.4 & 1.1 \\
\hline
\end{tabular}


TABLE 4.2. Radionuclide Activity of Surface Soil Samples from the Pocatello Area, $\mathrm{PCi} / \mathrm{g}$ (McNabb, Kirk, and Thompson 1979)

\begin{tabular}{|c|c|c|c|c|c|}
\hline Location & $238_{\mathrm{U}}$ & ${ }^{234} \mathrm{U}$ & ${ }^{230} \mathrm{Th}$ & ${ }^{210} \mathrm{Po}$ & ${ }^{232} \mathrm{Th}$ \\
\hline $\mathrm{F}$ & 2.2 & 2.2 & 3.1 & 3.8 & 0.7 \\
\hline G & 2.9 & 2.6 & 1.1 & 8.0 & 0.4 \\
\hline$H$ & 1.4 & 1.5 & 1.2 & 2.8 & 0.7 \\
\hline I & 13 & 13 & 9 & 9 & 0.5 \\
\hline
\end{tabular}

rural areas in southeastern Idaho (Arthur and Markham 1984). Polonium concentrations in the media sampled near the radioactive waste disposal facility were equal to or less than the values for the rural areas. Concentrations of 210 po in soils and deer mouse hide and carcass samples at locations $\mathrm{C}, \mathrm{J}$, and $\mathrm{K}$ (Figure 4.2 ) were statistically greater than the other locations. The mean ${ }^{210} \mathrm{Po}_{0}$ concentration in soils and deer mouse tissues near the phosphate plants were four and three times greater than the control values. No statistical difference was observed for ${ }^{210} \mathrm{Po}_{0}$ concentrations in vegetation at the different sampling locations, which suggests that the deer mouse concentration of $210 \mathrm{po}_{\mathrm{o}}$ is probably due to contact with contaminated soils. The 210 po concentrations were highest at the sample locations $\mathrm{K}$ and $\mathrm{J}(6.2$ and $2.6 \mathrm{pCi} / \mathrm{g})$ downwind of the phosphate plants and lowest at the airport $(2.3 \mathrm{pCi} / \mathrm{g}), 3.2 \mathrm{~km}$ (2 miles) west of the plants. The ${ }^{210} \mathrm{Po}_{0}$ concentrations in the soils at the background sites, Arco and Idaho Falls, were 1.4 to $1.5 \mathrm{pCi} / \mathrm{g}$.

Severson and Gough (1976) found that the processing plants at Pocatelio have a direct influence on the elemental content of local soil and vegetation. Samples taken at approximate logarithmic intervals up to $64 \mathrm{~km}$ (40 mi les) northeast (downwind) and southwest (upwind) of the phosphorus processing plants showed a direct correlation between concentration of certain elements and distance from the processing plants.

Very similar results were obtained by Johnson et al. (1980), who measured the uranium content in soils $10 \mathrm{miles}$ upwind to 10 miles downwind of the phosphorus processing plants in Pocatello. The concentration of uranium in the soils was about $3 \mathrm{ppm}(1 \mathrm{pCi} / \mathrm{g} 238 \mathrm{U})$ in both the surface and subsurface soils upwind and at distances greater than 6 miles downwind. At less than 6 miles 
downwind, the uranium concentration increased closer to the plant to a high of $6.9 \mathrm{ppm}\left(\sim 2 \mathrm{pCi} / \mathrm{g}^{238} \mathrm{U}\right)$ at only $0.5 \mathrm{mile}$ from the plants.

\subsection{OISTRIBUTION OF RADIONUCLIDES FROM COMMERCIAL USE OF BYPRODUCTS}

The byproduct slag from the thermal process plants has been used as a construction material in both Pocatello and Soda Springs. Most of the uranium and radium in the ore are contained in the slag, which then becomes a source of gamma radiation. In addition, ${ }^{222} R_{n}$ is produced from the decay of $226_{R a}$. Due to the refractory nature of the slag, the radon-emanating fraction is likely to be low, and radon release may not be significant.

The State of Idaho prohibited use of slag in habitable structures in 1977 , but it is still being used for road construction, for railroad bed ballast, and for other general construction uses. In 1974, about $15 \mathrm{Ci}$ of radium were distributed into the environment around Pocatello, as shown in Table 4.3. In the Soda Springs area from 1972-1974, an average of $6 \mathrm{Ci} /$ year of radium was distributed into the environment, as shown in Table 4.4 (Boothe 1977).

During 1977, a gamma survey truck operated by the EPA and the Idaho Radiation Control office scanned the towns of Soda Springs and Pocatello to detect elevated radiation levels coming from phosphate slag used within structures. A detailed description of the mobile gamma ray logging system is given by Hans et al. (1978). A summary of the results is provided by Peterson (1979).

TABLE 4.3. Distribution of Radium in Environs from the Comnercial Use of Slag--Pocatello Area, 1974. Assumes slag contains $35 \mathrm{pCi} / \mathrm{g}$ radium (Boothe 1977 ).

\begin{tabular}{l} 
Use \\
\hline Roads \\
Roads \\
Roads \\
General construction \\
Railroad bedding \\
Farmers \\
Concrete \\
Miscellaneous
\end{tabular}

\begin{tabular}{l} 
Location \\
\hline Streets of Pocatello \\
Streets of American Falls \\
Bannock County \\
Bannock County \\
Unknown \\
Bannock County \\
Pocatello \\
Unknown
\end{tabular}

$m \mathrm{C} j / \mathrm{y} r$
562.9
251.0
$5,514.2$
886.9
$4,741.0$
$1,885.7$
91.6
$1,519.0$
$15,462.0$


TABLE 4.4. Distribution of Radium in Environs from the Commercial Use of Slag--Soda Springs Area, 1972-74. Assumes slag contains $35 \mathrm{pCi} / \mathrm{g}$ radium (Boothe 1977).

\begin{tabular}{l} 
Use \\
\hline Roads \\
Roads \\
Roads \\
Concrete \\
General Construction \\
Railroad bedding
\end{tabular}

Location
Streets of Soda Springs
Streets of Montpelier
Caribou County
Caribou County
Caribou County
Unknown

Total

$m C i / y r$
46.8
37.2
$2,131.2$
265.2
732.9
$2,857.7$
$6,071.0$

Of the 1,082 structures in Soda Springs, 340 showed elevated gamma levels. In Pocatello, 2,035 structures with elevated gamma levels were detected. The survey was unable to positively identify slag-containing structures because of the added presence of slag in streets, sidewalks, and driveways.

A door-to-door survey in Soda Springs checked 278 structures suspected of being built with slag. Of these, $156(56 \%)$ were found to contain slag. observed average gamma levels in these structures ranged from 11 to $50 \mu R / h$ including background. The mean value was slightly over $28 \mu \mathrm{R} / \mathrm{h}$. Normal background was approximately $10 \mu R / h$.

During the summer of 1978, radon progeny measurements were made by the EPA and the Idaho Radiation Control office in 107 of the locations where slag was used in construction. The measurements ranged from 0.0005 to 0.046 working level (WL) with a median value of $0.0053 \mathrm{WL}$. Estimated normal background is $0.005 \mathrm{WL}$; the EPA guideline is $0.02 \mathrm{WL}$. Radon measurements made at the same locations at the same time ranged from 0.05 to $7.42 \mathrm{pCi} / 1$ with a median value of $1.2 \mathrm{pCi} / 1$. When comparing the radon and radon progeny data from each location, the median equilibrium was about $43 \%$. The value of these determinations is limited as they are grab samples taken during the summer, and it is well known that radon and radon progeny levels vary greatly with barometric pressure, temperature, ventilation, season of the year, etc.

Year-long, integrated Wh samples were made at four locations in Soda Springs where slag was used. The annual average values were $0.0077 \mathrm{WL}$, $0.0113 \mathrm{WL}, 0.0089 \mathrm{WL}$, and $0.0141 \mathrm{WL}$. Results from the year-long samples also 
indicate a slight increase during the summer, in contrast to the traditional understanding of seasonal variations in radon and radon progeny levels (Peterson 1979).

A study of slag use in homes in Butte, Montana, found the radon exhalation rate from slag to be very $1 \mathrm{ow}, 18$ to $30 \mathrm{pCi} / \mathrm{m}^{2} / \mathrm{min}$ compared with 3400 to $3822 \mathrm{pCi} / \mathrm{m}^{2} / \mathrm{min}$ for phosphate ore, even though the ${ }^{226} \mathrm{Ra}$ content was essentially the same for the ore and the slag (Lloyd 1983). Radon exhalation was lawer from slag than from natural decomposed granite soils in the Butte area. The author concluded that the radon exhalation from slag did not contribute to the elevated radon levels in Butte homes.

An extensive door-to-door survey similar to the Soda Springs survey has not been conducted in Pocatello; however, gamma levels have been reported for a variety of locations in Pocatello (Table 4.5). Table 4.5 gives the background level as $6 \mu \mathrm{R} / \mathrm{h}$. Others have reported it as high as $11 \mu \mathrm{R} / \mathrm{h}$ (Hans et al. 1978). Readings throughout the city have been as high as $44 \mu R / h$ (Hans et al. 1978) and average about $15 \mu \mathrm{R} / \mathrm{h}$ as indicated in Table 4.5.

Tables 4.3 and 4.4 showed that the primary use of slag was for road construction. In addition to elevated gamma levels shown in Table 4.5, the possibility of contamination of soils next to roadways exists. Surface soils next

\section{TABLE 4.5. Gamma Survey, Pocatello Area [gross readings taken $1 \mathrm{~m}(3.3 \mathrm{ft}$ ) above surface (Boothe 1977)]}

\begin{tabular}{lc}
\multicolumn{1}{c}{ Location } & $\mu R / h$ \\
\cline { 2 - 2 } Average background in city & 6 \\
Indian Hills School (new asphalt) & 9 \\
Cedar Hills Drive & 12 \\
Railroad grade throughout city & 9 \\
Second Avenue along Ross Park & 12 \\
South end of Arthur Avenue & 12 \\
Benton Avenue from Arthur to Fifth & 23 \\
Yellowstone Avenue & $18-35$ \\
Pocatello shopping mall parking lot & 37 \\
Holiday Inn parking lot & 29 \\
Holiday Inn sidewaik & 10 \\
Wilcox School area & 32 \\
Chubbuck School playground & 26 \\
& 15
\end{tabular}


to road beds were found to have elevated levels of uranium. Up to $18 \mathrm{ppm}$ of uranium was measured in soils $1 \mathrm{~m}(3.3 \mathrm{ft})$ from roads paved using slag. This amount compares with $3.6 \mathrm{ppm}$ background levels. The roads were paved with a 94\% slag/6\% asphalt mixture, a typical aggregate/asphalt mix for road paving. The study found that contamination of the soils is probably due to abrasion of slag particles in the road rather than from leaching.

Aerosol samples were taken $1.5 \mathrm{~m}(4.9 \mathrm{ft})$ above ground next to a roadway paved with slag (Melville 1980; Melville et al. 1981). The dust particles $>5 \mu \mathrm{m}$ that were collected from the aerosol samples were analyzed, and the uranium content calculated to be $0.043 \mathrm{pCi} 238 \mathrm{v} / \mathrm{m}^{3}$. These large particles are not an important radiological health consideration. Only smaller particles 0.01 to $5.0 \mu m$ are retained in the respiratory system. Based on the results for the larger particles, the ${ }^{238} \mathrm{U}$ content in the small particle range 10.4 to $5.0 \mu \mathrm{m})$ was estimated to be less than $0.03 \mu \mathrm{g} / \mathrm{m}^{3}$ of air. The authors concluded that this level was sufficiently low as to not cause serious concern but recommended that uranium progeny products such as ${ }^{226} \mathrm{Ra},{ }^{222} \mathrm{Rn}, 210_{\mathrm{Po}}$, and $210_{\mathrm{Pb}}$ also be evaluated.

\subsection{RADIONUCLIDES IN WATER}

No contamination of surface or ground waters in southeastern Idaho has been linked directly to phosphate processing plants. However, elevated beta activity has been found in the 0ld Airport well, 1 mile north of the FMC thermal process plant near Pocatello (Boothe 1977). The beta activity has been identified as $40 K$. If this potassium, which is highly soluble, is entering the ground water from phosphate ponds or discharges, then the possibility of radionuclide contamination exists as well (Boothe 1977).

The $40_{K}$ concentration and beta activity for several wells near the FMC plant are listed in Table 4.6. The $40 \mathrm{~K}$ concentration in the 01d Airport tap jumped dramatically between 1972 and 1973. Furthermore, the concentration in the FMC well increased between 1973 and 1975. The other wells in the area show no increase in $40 K$ concentration over the same time.

It has been theorized that the elevated $40_{K}$ levels may be due to leaching from waste ponds at the FMC plant. While the hydrology for the area is not 
TABLE 4.6. Beta Activity and ${ }^{40} \mathrm{~K}$ Concentration in wells Near the FMC Pocatello Plant (Baston 1976; Boothe 1977)

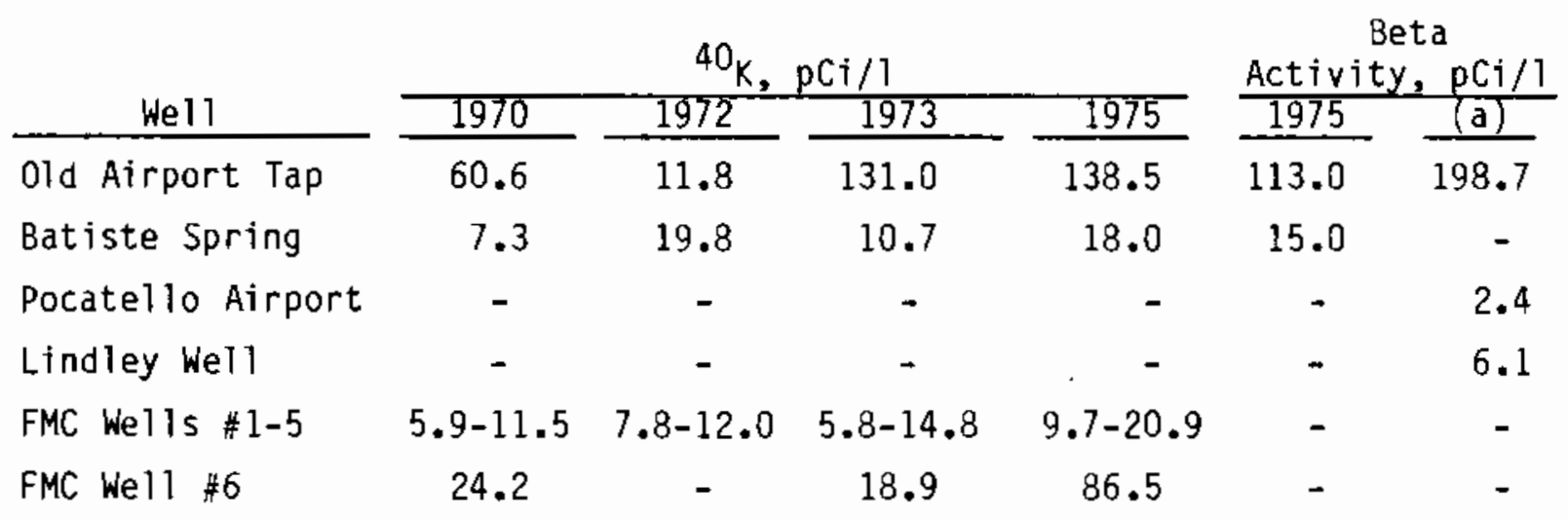

(a) Data taken from Boothe (1977); no date given.

well established, the direction of flow is generally accepted as northerly. The old Airport tap (close to Location $K$ in Figure 4.2) is less than 1 mile north of the FMC plant. The Lindley well and Batiste Springs (close to Location $F$ in Figure 4.2) are about 1 mile from the plant. The Pocatelio Airport well is 2 miles west northwest of the plant. The FMC wells are all located just north of waste ponds at the plant. The fact that other wells do not show contamination suggests that the mechanism of hydrologic transport is not appropriate or is limited to specific isolated coordinates (Baston 1976).

In evaluations of surface water, the Portneuf River has been sampled upstream and downstream of the two phosphate processing plants near Pocatello (Eadie and Bernhardt 1977; Eadie, Bernhardt, and Boysen 1978). Prior to the analysis, the suspended solids were allowed to settle out, and both the liquid and the insoluble material were analyzed. The radionuclide concentrations in the upstream and downstream liquid were basically identical. However, the uranium and thorium contents of the suspended solids in the downstream sample were an order of magnitude higher than in the upstream sample. The radionuclide content of both the liquid and suspended solids is well within the range of naturally occurring radioactivity. Any future efforts to evaluate the radionuclide content in rivers and streams near phosphate plants shouid include sediment sampling (Eadie and Bernhardt 1977; Eadie, Bernhardt, and Boysen 1978). 


\subsection{ESTIMATE OF HEALTH IMPACT}

The two areas are of primary concern with respect to the health impact of phosphate rock processing and byproduct utilization in southeastern Idaho are as follows:

- inhalation of airborne radionuclides emitted from calciner stacks

- gamma and radon progeny exposure associated with use of byproduct slag in construction.

\subsection{AIRBORNE RADIONUCLIDES FROM THERMAL PROCESS PLANTS}

The EPA has estimated the radiation exposure and health risks associated with the elemental phosphorus plant operations in Pocatello and Soda Springs (EPA 1984a). Doses were calculated using the AIRDOS-EPA/DARTAB computer mode? developed by Oak Ridge National Laboratory (EPA 1979; Begovich 1981). Data required as input included the calciner stack emissions (see Table 3.9), population distributions, and meteorological data as shown in Table 5.1. The estimated radiation dose to lung and the estimated fatal cancer risks are shown in Table 5.2. The airborne emissions and the risk of fatal cancer for the thermal process plants are much higher than estimated for the wet process plants. (The risks from wet process plants were made using a generic floridabased plant.)

Emission limits as low as $1.0 \mathrm{Ci} /$ year of 210 po were considered by the EPA (Stula et a). 1983), but in 1985 the EPA issued a standard of $21 \mathrm{Ci} /$ year of 210 Po emissions from calciner stacks at elemental phosphorus plants. This

IABLE 5.1. Input Data used in Dose and Risk Calculations (EPA 1984a)

\begin{tabular}{|c|c|c|c|c|}
\hline \multirow[b]{2}{*}{ Plant } & \multicolumn{2}{|c|}{$\begin{array}{c}\text { Calciner Emissions, } \\
\mathrm{Ci} / \mathrm{yr}\end{array}$} & \multirow{2}{*}{$\begin{array}{l}\text { Number of Persons } \\
\text { within } 80 \mathrm{~km} \\
\end{array}$} & \multirow{2}{*}{$\begin{array}{c}\text { Source of } \\
\text { Meteorological } \\
\text { Data }\end{array}$} \\
\hline & $210_{\mathrm{Po}}$ & $210_{\mathrm{Pb}}$ & & \\
\hline $\begin{array}{l}\text { FMC } \\
\text { Pocatel10 }\end{array}$ & 9 & 0.1 & 140,000 & Pocatello Ajrport \\
\hline $\begin{array}{l}\text { Monsanto } \\
\text { Soda Springs }\end{array}$ & 21 & 5.6 & 80,000 & Pocatello Airport \\
\hline
\end{tabular}


IABLE 5.2. Estimate of Radiation Dose and Fatal Cancer from Airborne Radionuclide Emissions from Calciners at Elemental Phosphorus Plants (EPA 1984a)

\begin{tabular}{|c|c|c|c|c|}
\hline \multirow[b]{2}{*}{ Plant } & \multicolumn{2}{|c|}{ Radiation Dose to Lung } & \multicolumn{2}{|c|}{ Fatal Cancer Risks } \\
\hline & $\begin{array}{c}\text { Nearby } \\
\text { Individuals, } \\
\text { mrem/yr } \\
\end{array}$ & $\begin{array}{c}\text { Regional } \\
\text { Population, } \\
\text { person-rem } / \text { yr }\end{array}$ & $\begin{array}{c}\text { Lifetime Risk } \\
\text { to Nearby } \\
\text { Individuals }\end{array}$ & $\begin{array}{c}\text { Regiona! } \\
\text { Population } \\
\text { Fatal Cancers/yr }\end{array}$ \\
\hline $\begin{array}{l}\text { FMC } \\
\text { Pocatello }\end{array}$ & 290 & 1170 & 0.0005 & 0.027 \\
\hline $\begin{array}{l}\text { Mons anto } \\
\text { Soda Springs }\end{array}$ & 610 & 750 & 0.001 & 0.018 \\
\hline
\end{tabular}

standard would not decrease enissions but would assure that enissions would not increase. The decision to adopt the higher standard was based on the low aggregate risk and the high cost of controls versus the public health benefits (EPA 1984a).

Because of the complex topography of the area and the lack of appropriate meteorological data, in particular for Soda Springs where Pocatello Airport data were used for the analysis, dose and risk estimates using AIRDOS-EPA are probably in error. Further analysis and modeling using appropriate meteorological data are needed.

\subsection{GAMMA AND RADON/PROGENY EXPOSURE FROM SLAG}

As discussed earlier, a survey of 278 homes in Soda Springs suspected of being built with slag found the mean gamma level to be $28 \mu R / h$ compared with a normal background of $10 \mu \mathrm{R} / \mathrm{h}$. Using a cancer induction risk from gamma radiation of 0.3 per 1000 man-rem, Peterson (1979) estimated about 5 excess cancer deaths/70 years based on the current population in Soda Springs. Based on these results, Peterson concluded that it would be prudent to continue the ban on construction use of slag in structures but that remedial action on existing structures was not warranted.

Grab-sample radon progeny WL measurements were made at $107 \mathrm{slag-}$ contaminated structures in Soda Springs during the summer of 1978 (Peterson 1979). These samples had a mean average of 0.0053 wL compared with normal background of $0.005 \mathrm{WL}$. Four year-long integrated $\mathrm{WL}$ samples were taken with a 
radon progeny integrating sampling unit (RPISU) in Soda Springs; the average values were $0.0077,0.0113,0.0089$, and $0.0141 \mathrm{WL}$. The year-tong samples are generally believed to be more accurate than grab samples, particularly samples taken during the summer as in Soda Springs (Ronca-Battista, Magno, and Windham 1986). If the year-long WL values are used, the mean value is $0.009 \mathrm{WL}$, and an estimated $23 \%$ of the structures would exceed the EPA guideline of $0.02 \mathrm{WL}$ (Peterson 1979). Clearly, additional sampling is needed to determine if radon represents a health impact in Soda Springs. Based on the measurements of radon exhalation from slag by the Montana Department of Health and Environmental Sciences (Lloyd 1983), it is unlikely that slag, because of its low enanating power, is the cause of elevated radon levels in Soda Springs homes.

\subsection{RADIONUCLIDE EMISSIONS FROM WET PROCESS PLANTS}

The EPA (1984a) also estimated the health impact of radionuclides in particulate enissions from a reference wet process phosphoric acid plant. Emissions of primary concern for the reference plant were from diammonium phosphate (DAP) and TSP dryers. Previous estimates of radionuclide enissions from the J. R. Simplot Co. plant in Pocatello were very similar to those used by the EPA for their reference plant (Table 5.3) (Eadie, Bernhardt, and Boysen 1978). The radiation dose and fatal cancer risk to nearby individuals calculated for the reference plant and shown in Table 5.4 can be used as a preliminary estimate for the J.R. Simplot Co. plant.

The 1975 study of the J. R. Simplot Co. plant (Eadie, Bernhardt, and Boysen 1978) identified the TSP dryer as the primary source of emissions. The TSP plant has been modified since this study was conducted, and is no longer a significant source of airborne radionuclides. The 1975 study did not include calciner emissions, but a recent study has shown these emissions to be low (EPA 1987). Current enissions from the J. R. Simplot Co. facility may be significantly lower than previously reported. As a result, the numbers in Table 5.4, already several orders of magnitude lower than those in Table 5.1 for the thermal process plants in Idaho, probably overestimate the risk for the $J$. R. Simplot Co. facility. 
TABLE 5.3. Airborne Radionuclide Particulate Emissions from Wet Process Phosphoric Acid Plants, mCj/yr

$\begin{array}{lcc} & \begin{array}{c}\text { EPA Reference } \\ \text { Plant (a) }\end{array} & \text { J. R. Simplot Co. Plant, } \\ 238_{\mathrm{U}} & 6.7 & 5.10 \\ 234_{\mathrm{U}} & 6.7 & 5.10 \\ 230_{\mathrm{Th}} & 6.7 & <5 \\ 226_{\mathrm{Ra}} & 0.97 & 5.10 \\ 210_{\mathrm{Pb}} & 3.4 & 5.10 \\ 210_{\mathrm{Po}} & 3.4 & <5\end{array}$

(a) EPA (1984a).

(b) Eadie, Bernhardt, and Boysen (1978).

IABLE 5.4. Health Impact of Airborne Radionuclide Particulate Emissions from a Wet Process Phosphoric Acid Plant (EPA 1984a)

\begin{tabular}{|c|c|c|c|}
\hline Source & $\begin{array}{r}\text { Radiation } \\
\text { Nearby Ind } \\
\text { mrem }\end{array}$ & $\begin{array}{l}\text { e to } \\
\text { uals, }\end{array}$ & $\begin{array}{c}\text { Lifetime Fatal Cancer } \\
\text { Risk to Nearby } \\
\text { Individuals }\end{array}$ \\
\hline $\begin{array}{l}\text { DAP and ISP } \\
\text { Dryer Emissions }\end{array}$ & $\begin{array}{l}\text { Lung } \\
\text { Endosteum } \\
\text { Red Marrow } \\
\text { Kidney }\end{array}$ & $\begin{array}{l}1.2 \\
2.2 \\
0.15 \\
0.07\end{array}$ & $2 \times 10^{-6}$ \\
\hline
\end{tabular}




\subsection{CONCLUSIONS AND RECOMMENDATIONS}

Dispersion of radionuclides into the environment by phosphate processing plants has been the subject of much research and study; however, there is still no clear understanding of the subsequent total dose. The following conclusions and recommendations were drawn from the review of pertinent literature.

Two primary radionuclide pathways to the environment have been identified:

- airborne release of volatile radionuclides, primarily 210 po, from calciner stacks at the two elemental phosphorus plants

- byproduct slag use as an aggregate for construction in Soda Springs and Pocatello.

The health impact of both scenarios has been estimated by the EPA (for ${ }^{210}$ Po $_{0}$ ) and the Idaho Department of Health and Welfare (for slag).

Two other radionuclide pathways to the environment that require further study were identified:

- radon exhalation from phosphogypsum and ore piles

- contamination of surface and ground waters by wastewater from the processing plants.

Recommendations for further study to provide a basis for a complete dose assessment are as follows:

- Determine gamma exposure caused by use of slag in roads, sidewalks, etc. in the Pocatello and Soda Springs area.

- Measure radon flux from phosphogypsum, ore, and slag piles.

- Measure airborne particulate activity in Pocatello and Soda Springs and correlate results with airborne emissions from phosphate processing plants (calciner off-gas, dust from ore piles, etc.) through air dispersion modeling.

- Determine the background contribution of $210_{\mathrm{Po}},{ }^{210} \mathrm{~Pb},{ }^{222} \mathrm{Rn},{ }^{238} \mathrm{U}$, ${ }^{226}{ }_{R u}$, and gamma radiation to the total radiation dose to the communities of Pocatello and Soda Springs. 


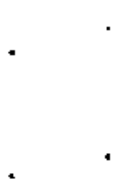




\subsection{REFERENCES}

Arthur, W. J. III, and 0. D. Markham. 1984. "Polonium-210 in the Environment Around a Radioactive Waste Disposal Area and Phosphate Ore Processing Plant." Health Physics 46(4):793-799.

Baston, V.F. 1976. Assessment of Radioactivity Associated with Surface and Subsurface Waters Located Within and Outside FMC's Pocatello Facility. Prepared for FMC Corporation by Energy Incorporated, Idaho Fa71s, Idaho.

Begovich, C. L., K. F. Eckerman, E. L. Schlatter, S. Y. Ohr, and R. 0. Chester. 1981. DARTAB: A Program to Combine Airborne Radionuclide Environmental Exposure Data with Dosimetric and Health Effects Data to Generate Tabulation of Predicted Impacts. ORNL-5692, Oak Ridge National Laboratory, Oak Ridge, Tennessee.

Boothe, G. F. 1977. "The Need for Radiation Controls in the Phosphate and Related Industries." Health Physics 32(4):285-290.

Buttelman, J. D. 1986. FMC Corporation EPA Method Five Stack Sampling Quality Assurance Manual. FMC Corporation, Pocatelio, Idaho.

Chemical Marketing Reporter Staff. 1981. "Chemical Profile--Elemental Phosphorus." Chemical Marking Reporter, March 9, New York, New York.

Chemical Marketing Reporter Staff. 1983. "Chemical Profile--Phosphoric Acid." Chemical Marketing Reporter, July 18, New York, New York.

Eadie, G. G., and D. E. Bernhardt. 1977. Radiological Surveys of Idaho Phosphate Ore Processing--the Thermal Process Plant. ORP/LV-77-3, Office of Radiation Programs, U. S. Environmental Protection Agency, Las Vegas, Nevada.

Eadie, G. G., and D. L. Lambdin. 1980. Airborne Particulate Radioactivity Measurements in Pocatello, Idaho. ORP/LV-80-4, Office of Radiation Programs, U. S. Environmental Protection Agency, Las Vegas, Nevada.

Eadie, G. G., D. E. Bernhardt, and G. A. Boysen. 1978. Radiological Surveys of Idaho Phosghate Ore Processing--The Wet Process PIant. ORP/L V-78-1, Office of Radiation Programs, U. S. Environmental Protection Agency, Las Vegas, Nevada.

Freeman, H. D., and J. N. Hartley. 1985. Radon Flux Measurements on Gardinier and Royster Phosphogypsum Piles Near Tampa and Mulberry, Florida. EPA-520/5-85-029, U.S. Envi ronmentai Protection Agency, Office of Radiation Programs, Montgomery, Alabama.

Gallaghar, R. G. 1976. Health Physics Survey of the FMC Corporation Elemental Phosphorus Plant--Pocatello, Idaho. Applied Health Physics, Inc., Pocatelio, Idaho. 
Guimond, R. J., and S. T. Windham. 1975a. Radioactivity Distribution in Phosphate Products, ByProducts, Effluents, and Wastes. ORP/CSD-75-3, Criteria and Standards Programs, Criteria and Standards Division, Office of Radiation Programs, U.S. Environmental Protection Agency, Washington, D.C.

Guimond, R. J., and S. T. Windham. 1975b. "Radioactivity Distribution in Phosphate Products, Byproducts, Effluents, and Wastes." Presented at the American Chemical Society Annual Meeting, Chicago, Illinois, August 24-29.

Hans, J. M., G. G. Eadie, J. Thrall, and B. Peterson. 1978. Above Ground Gamma Ray Logging for Locating Structures and Areas Containing Elevated Levels of Uranium Decay Chain Radionuclides. ORP/LV-78-2, Office of Radiation Programs, U. S. Environmental Protection Agency, Las Vegas, Nevada.

Johnson, R., C. M. Wai, B. McVeety, H. Lee, and H. Willmes. 1980. "Uranium in Soil Around Phosphate Processing Plants in Pocatello, Idaho." Bull. Environ. Contam. Toxicol. 24(5):735-738.

Jongleaux, R. F. 1984a. Emission Testing of Calciner Off-Gases at FMC Elemental Phosphorus Plant, Pocatello, Idaho, Volumes I \& II. Prepared for U.S. Environmental Protection Agency under Contract No. 68-02-3174 by Radian Corporation, Research Triangle Park, North Carolina.

Jongleaux, R. F. 1984b. Emission Testing of Caiciner Off-Gases at Monsanto Elemental Phosphorus Plant, Soda Springs, Idaho, Volumes I \& II. Prepared for U.S. Environmental Protection Agency under Contract No. 68-02-3174 by Radian Corporation, Research Triangle Park, North Carolina.

Lloyd, L. L. 1983. Evaluation of Radon Sources and Phosphate Slag in Butte, Montana. EPA-520/6-83-026, U.S. Environmenta1 Protection Agency, Washington, D. C.

McNabb, G. J., J. A. Kirk, and J. L. Thompson. 1979. "Radionuclides from Phosphate-0re-Processing Plants: The Environmental Impact After 30 Years of Operation." Health Physics 37(4):585.

Melville, C. 1980. Uranium in Idaho's Roadbeds Constructed of Phosphate Slag--Environmental Impacts and Recovery. NSF-SOS Project Report, Department of Chemistry, University of Idaho, Moscow, Idaho.

Melville, C. M., C. M. Wai, M. Collopy, and H. Willmes. 1981. "Uranium Dispersion Along Roads Paved with Phosphate Slag." Bull. Environ. Contam. Toxicol. 27(4):470-473.

National Council on Radiation Protection and Measurements (NCRP). 1975. Natural Background Radiation in the United States. NCRP Report No. 45, Washington, D.C. 
PEDCo Environmental, Inc. 1983. Evaluation of Waste Management for Phosphate Processing: Interim Report on Characterization of Phosphate Processing Wastes and Selection of Management Practices and Sites to be Monitored. Prepared for U. S. Environmental Protection Agency under Contract No. 68-033036, Cincinnati, Ohio.

PEI Associates. 1985. Data Describing Phosphogypsum Piles. Prepared for U.S. Environmental Protection Agency Under Contract No. 68-02-3878, Cincinnati, Ohio.

PEI Associates. 1986. Data Summary Report--Radionuclide Air Sampling at Florida Phosphogypsum Stacks. Prepared for U.S. Environmental Protection Agency under Contract No. 68-02-3878, Cincinnati, 0hio.

Peterson, B. H. 1979. Field Surveys of Phosphate Slag Use for Construction Purposes in Soda Springs, Idaho. Idaho Department of Health and Welfare, Boise, Idaho.

Powel1, J. D. 1974. "Evaluation of Phosphate Resources in Southeastern Idaho." Idaho Bureau of Mines and Geology Information Circular 25.

Ronca-Battista, M., P. Magno, and S. Windham. 1986. "Uncertainties of Estimating Average Radon and Radon Decay Product Concentrations in Occupied Houses." Proceedings of Indoor Radon and Air Pollution Control Association Specialty Conference, Philadelphia, Pennsylvania.

Severson, R. C., and L. P. Gough. 1976. "Concentration and Distribution of Elements in Plants and Soils Near Phosphate Processing Factories, Pocatello, Idaho." Journal of Environmental Quality 5(4):476-482.

Smith, S. G. 1982. Particulate Emissions and Control Costs of Radionuclide Sources in Phosphate Rock Processing Plants. Prepared for U. S. Environmental Protection Agency under Contract No. 68-02-3515 by TRW Energy and Environmental Division, Research Triangle Park, North Carolina.

Stula, S., et a1. 1983. Control Technology Alternatives and Costs for Compliance--Elemental Phosphorus Plants. Prepared for U.S. Environmental Protection Agency under Contract No. $68-01-6429$ by Science Applications, Inc., La Jolla, California.

U.S. Atomic Energy Commission. 1970. Pocatello and Vicinity Environmental Air Sampling Results. U.S. Atomic Energy Commission Health Services Laboratory, Idaho Operations office, Idaho Falls, Idaho.

U.S. Environmental Protection Agency. 1973. Reconnaissance Study of Radiochemical Pollution from Phosphate Rock Mining \& Milling. Office of Enforcement, National Field Investigations Center, Denver, CoTorado. 
U.S. Envi ronmental Protection Agency. 1975. Preliminary Findings--Radon Daughter Levels in Structures Constructed on Reclaimed Florida Phosphate Land. Technical Note ORP/CSD-75-4, Criteria and Standards Division, Office of Radiation Programs, Washington, D.C.

U.S. Environmenta1 Protection Agency. 1979. AIRDOS-EPA, A Computerized Methodology for Estimating Concentrations and Dose to Man from Airborne Releases of Radionuclides. EPA/1-79-009, Office of Radiation Programs, Washington, D.C.

U.S. Environmental Protection Agency. 1984a. Background Information Document (Integrated Risk Assessment) Final Rules for Radionuclides--Volume II. EPA-520/1-84-022-2, Office of Radiation Programs, Washington, D.C.

U.S. Environmental Protection Agency. 1984b. Emissions of Lead-210 and Polonium-210 from Calciners at Elemental Phosphorus Plants: FMC PTant, Pocatello, Idaho. Office of Radiation Programs, Washington, D.C.

U.S. Environmental Protection Agency. 1984C. Emissions of Lead-210 and Polonium-210 from Calciners at Elemental Phosphorus Plants: Monsanto Plant, Soda Springs, Idaho. Office of Radiation Programs, Washington, D.C.

U.S. Envi ronmental Protection Agency. 1987. Emissions of Lead-210 and Polonium-210 from Phosphate Rock Calciners at Wet-Process Fertilizer Plant5: J. R. Simplot Plant, Pocatello, Idaho. Office of Radiation Programs, Washington, D.C. 
APPENDIX A

238 U AND ${ }^{232}$ Th DECAY SERIES 


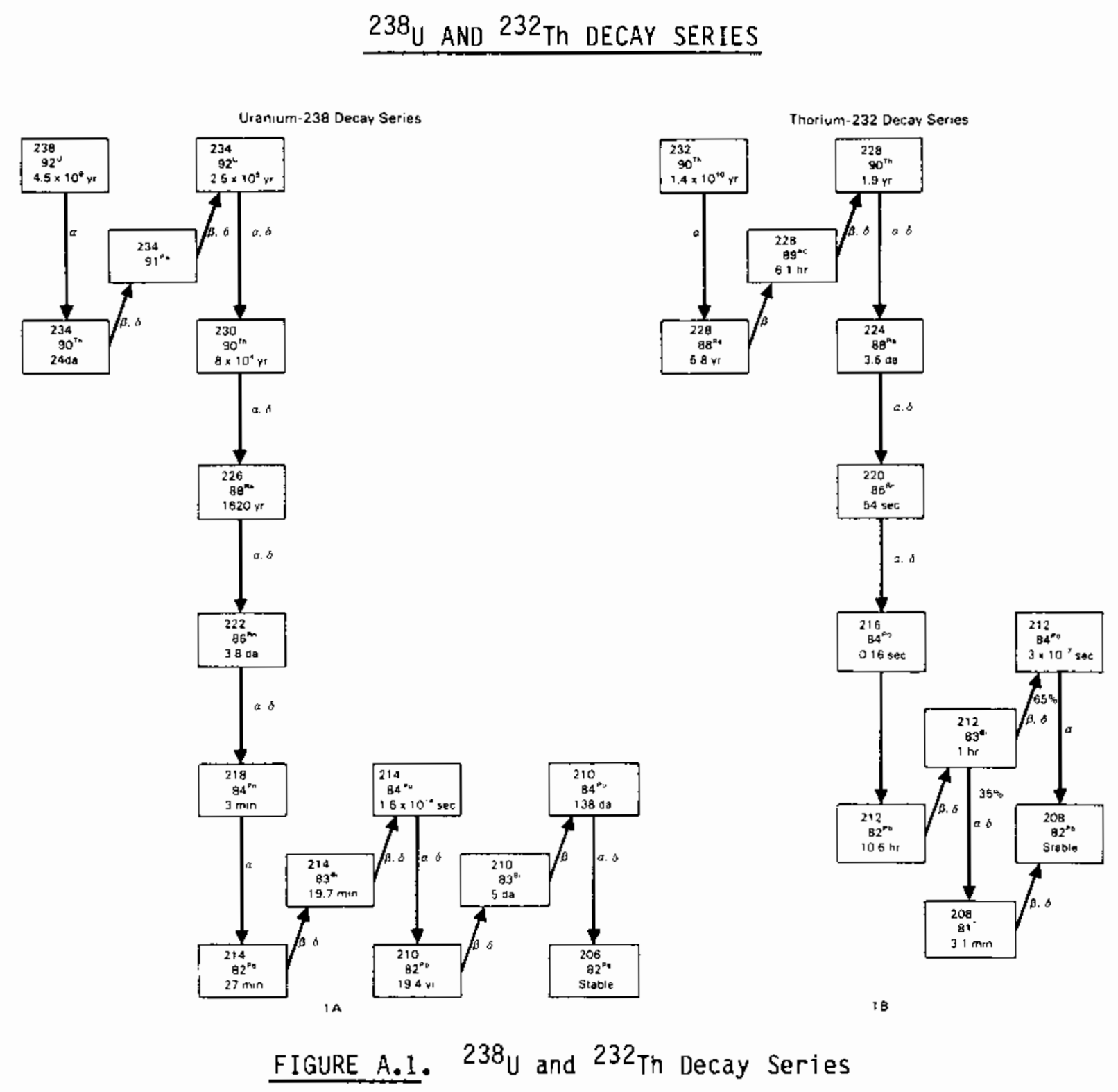




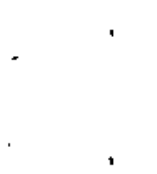


APPENDIX B

GLOSSARY OF TERMS AND ABBREVIATIONS 
APPENDIX B

GLOSSARY OF TERMS AND ABBREVIATIONS

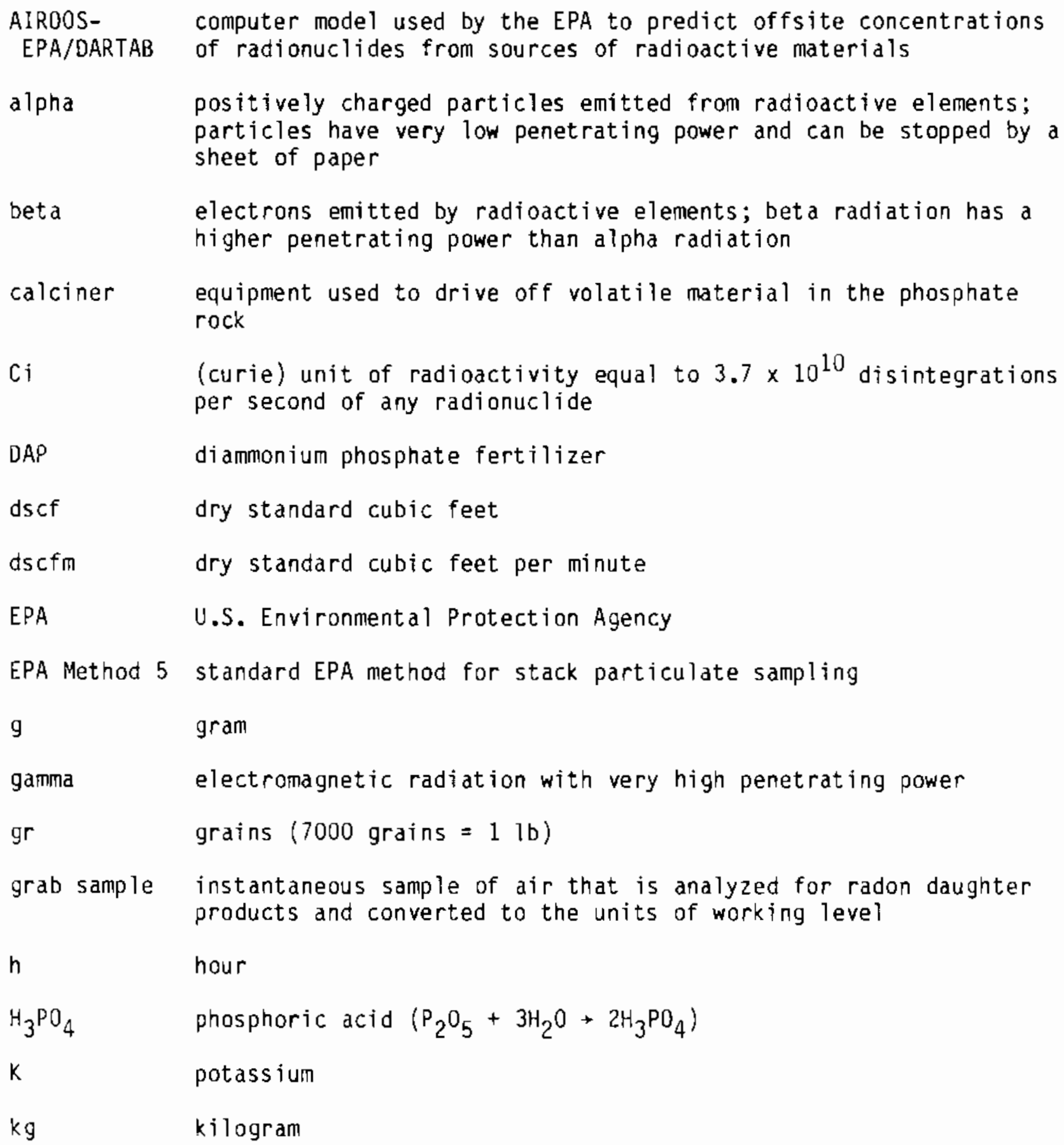


liter

$\begin{array}{ll}\mathrm{lb} / \mathrm{h} & \text { pounds per hour } \\ \mathrm{m}^{2} & \text { square meters } \\ \mathrm{m}^{3} & \text { cubic meters } \\ \mathrm{mC} i & \text { millicurie, } 10^{-3} \mathrm{Ci} \\ \mathrm{mrem} & \text { millirem, } 10^{-3} \text { rem } \\ \mathrm{P}_{2} \mathrm{O}_{5} & \text { phosphorus pentoxide } \\ \mathrm{P}_{4} & \text { elemental phosphorus } \\ \mathrm{Pb} & \text { lead } \\ \mathrm{pCi} & \text { picocurie, } 10^{-12} \mathrm{Ci} \\ \mathrm{ppm} & \text { parts per million }\end{array}$

phosphate rock containing $24 \%$ to $34 \% \mathrm{P}_{2} \mathrm{O}_{5}$, the remainder being primarily calcium; also contains small quantities of radionuclides

phosphogypsum solid byproduct of the wet process; primarily calcium sulfate

Po

polonium

$\mathrm{Ra}$

radium

radionuclide

radioactive element

radon the fraction of radon produced from radionuclide decay that emanating fraction

radon progeny escapes to the pore spaces
rem
a measure of radiation dose devised to take into account the biological effects of different types of ionizing radiation on humans
Rn radon
RPISU radon progeny integrating sampling unit
scf standard cubic feet 


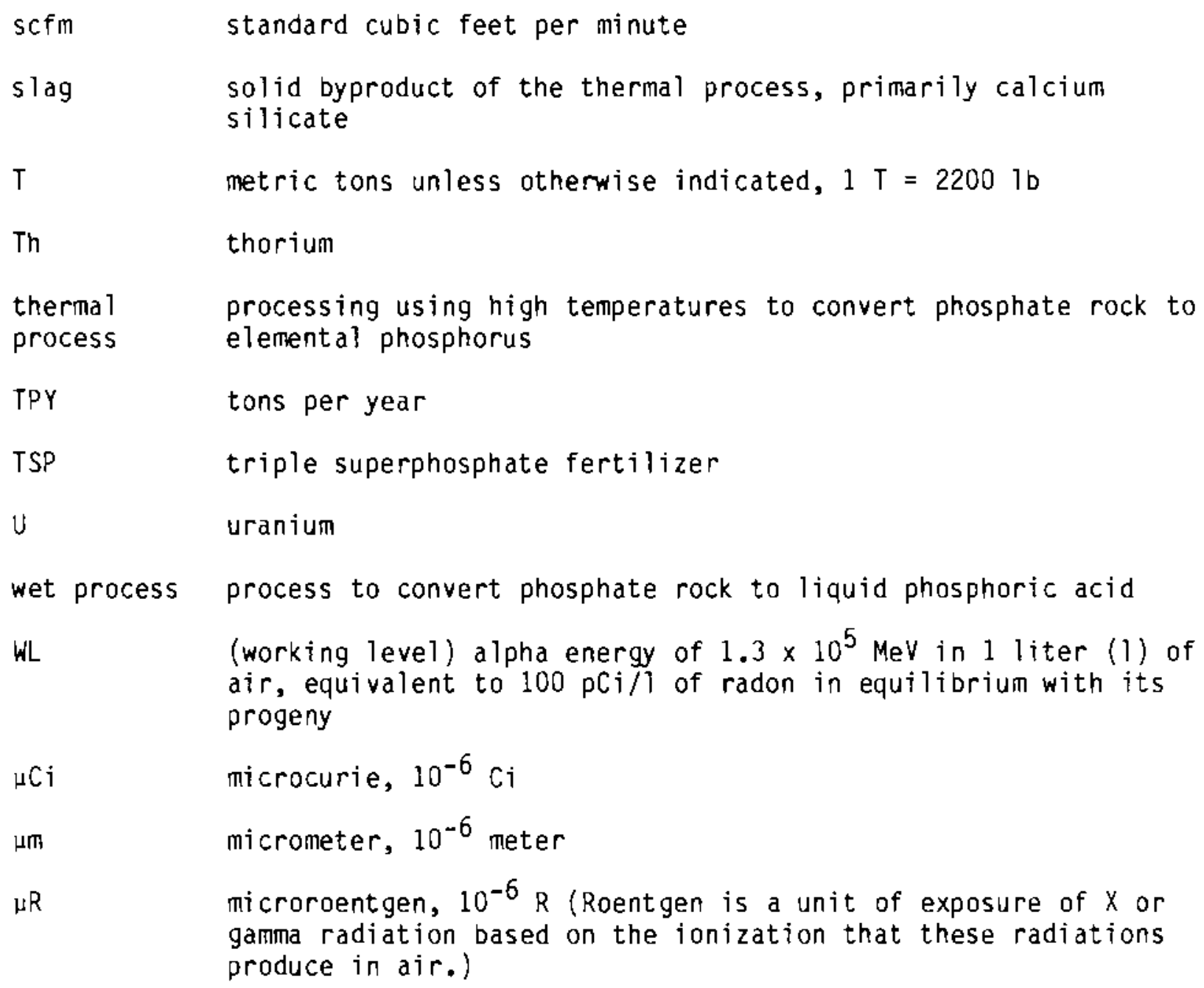



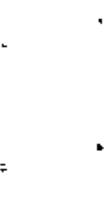

. 
APPENDIX C

BIBLIOGRAPHY 
APPENDIX C

BIBLIOGRAPHY

Alsager, M. D. 1978. "Idaho Phosphate Environmental Statement." Proceedings of Environmental Symposium. The Fertilizer Institute, New Orleans, Louisiana.

Andrews, V. E. 1981. Emissions of Naturally Occurring Radioactivity from Monsanto Elemental Phosphorus PTant. ORP/LV-81-5, Office of Radiation Programs, U.S. Environmental Protection Agency, Las Vegas, Nevada.

Andrews, V. E. 1981. Emissions of Naturally Occurring Radioactivity from Stauffer Elementa] Phosphorus Plant. ORP/LV-81-4, Office of Radiation Programs, U.S. Environmental Protection Agency, Las Vegas, Nevada.

Baes, C. F., and R. D. Sharp. 1981. A Di rectory of Parameters Used in a Series of Assessment Applications of the AIRDOS-EPA and DARTAB Computer Codes. ORNL-5720, Oak Ridge National Laboratory, Oak Ridge, Tennessee.

Baston, V.F. 1976. Assessment of Radioactivity Associated with Surface and Subsurface Waters Located Within and Outside FMC's Pocatello Facility. Prepared for FMC Corporation by Energy Incorporated, Idaho Falls, Idaho.

Battelle Memorial Institute. 1971. Inorganic Fertilizer and Phosphate Mining Industries Water Pollution Control. Final Report to U.S. Environmental Protection Agency, Washington, 0.C.

Begovich, C. L., K. F. Eckerman, E. L. Schlatter, S. Y. Ohr, and R. O. Chester. 1981. DARTAB: A Program to Combine Airborne Radionuclide Environmental Exposure Data with Dosimetric and Health Effects Data to Generate Tabulation of Predicted Impacts. ORNL-5692, Jak Ridge National Laboratory, Oak Ridge, Tennessee.

Boothe, G. F. 1977. "The Need for Radiation Controls in the Phosphate and Related Industries." Health Physics 32(4):285-290.

Cannon, M. R. 1980. Conceptual Models of Interactions of Mining and Water Resource Systems in the Southeastern Idaho Phosphate Field. Prepared for the office of Water Research and Technology, Washington, D.C., under Contract No. OWRT-C-7651.

Carter, R. A. 1978. "An Integrated Industry--Phosphate Mining and Militing in Idaho." Mining Engineering 30(1):29-36.

Cathcart, J. B., R. P. Sheldon, and R. A. Gulbrandsen. 1984. "Phosphate-Rock Resources of the United States." U.S. Geological Survey Circular 888. 
Chaco, E., and M. Molnau. 1979. "Erosion on Phosphate Mine Waste Dumps." ASAE paper No. 79-2535, American Society of Agricultural Engineers.

Coker, A. E. 1971. "Remote Sensing of Phosphates and Fluoride Pollution in the Karst Terrain of Florida." Presented at the National Water Hell Association Annual Meeting, Las Vegas, Nevada.

Corbet, T. F., Jr. 1980. Interactions between Open Pit Mining and Ground Water Flow Systems at the East Area of the Gay Mine, Idaho. Prepared for the Office of Water Research and Technology, Washington, D.C., under Contract No. OWRT-C-7651.

Day, R. L. 1973. Trends in the Phosphate Industry of Idaho and the Western Phosphate Field. Vol. 155, Idaho Bureau of Mines and Geology.

Eadie, G. G., and D. E. Bernhardt. 1977. Radiological Surveys of Idaho Phosphate Ore Processing--the Thermal Process Plant. ORP/LV-77-3, Office of Radiation Programs, U.S. Environmental Protection Agency, Las Vegas, Nevada.

Eadie, G. G., D. E. Bernhardt, and G. A. Boysen. 1978. Radiological Surveys of Idaho Phosphate Ore Processing--The Wet Process Plant. ORP/LV-78-I, Office of Radiation Programs, U.S. Environmental Protection Agency, Las Vegas, Nevada.

Eadie, G. G., and D. L. Lambdin. 1980. Airborne Particulate Radioactivity Measurements in Pocatel10, Idaho. ORP/LV-80-4, Office of Radiation Programs, U.S. Environmental Protection Agency, Las Vegas, Nevada.

Engineering-Science, Inc. 198U. Collection of Airborne Radon and Radioactive Particulates at the Monsanto Chemical Intermediates Columbia Elemental Phosphorus Plant, Columbia Tennessee. McLean, Virginia.

Evans, K. E. 1984. Proceedings of a Workshop on Engineering and Hydrology Research Needs for Phosphate Mined Lands of Idaho Held at Pocatello, Idaho on June 5-6, 1984. FSGTR/INT-192, U.S. Forest Service, Ogden, Utah.

Farmer, E. E. 1980. "Phosphate Mine Dump Hydrology." Symposium on Watershed Management, American Society of Civil Engineers, Boise, Idaho.

Fitzgerald, J. E., Jr., and E. L. Sensintaffar. Radiation Exposure From Construction Materials Utilizing By-Product Gypsum From Phosphate Mining. Criteria and Standards Division, Office of Radiation Programs, Eastern Env. Radiation Facility, U.S. Environmental Protection Agency, Montgomery, Alabama.

Freeman, H. D., and J. N. Hartley. 1985. Radon Flux Measurements on Gardinier and Royster Phosphogypsum Piles Near Tampa and Mulberry, Florida. EPA-520/5-85-029, prepared for U.S. Environmental Protection Agency, Office of Radiation Programs, Montgomery, Alabama. 
Gallaghar, R. G. 1976. Health Physics Survey of the FMC Corporation Elemental Phosphorus Plant--Pocatello, Idaho. Applied Health Physics, Inc., Pocatello, Idaho.

Good, P. C., T. N. Goff, and C. B. Daellenbach. 1981. Direct Preparation of Phosphoric Acid from Intermediate-Grade Western Phosphatic Shale. BUMINES-RI-8534, Bureau of Mines, Albany, Oregon.

Gough, L. P., and R. C. Severson. 1976. "Impact of Point Source Emissions from Phosphate Processing on the Element Content of Plants and Soils, Soda Springs, Idaho." In Proceedings 10th Annual Conference of Trace Substances for Environmental HeaTth, University of Missouri, Columbia, Missouri.

Guimond, R. J. 1976. "The Radiological Impact of the Phosphate Industry." Presented at the 8th Annual National Conference on Radiation Control, Springfield, Il1inois.

Guimond, R. J., and S. T. Windham. 1975. Radioactivity Distribution in Phosphate Products, Byproducts, Effluents, and Wastes. 0RP/CSD-75-3, Criteria and Standards Programs, Criteria and Standards Division, Office of Radiation Programs, U.S. Envi ronmental Protection Agency, Washington, D.C.

Guimond, R. J., and S. T. Windham. 1975. "Radioactivity Distribution in Phosphate Products, Byproducts, Effluents, and Wastes." Presented at the American Chemical Society Annual Meeting, Chicago, I11inois, August 24-29.

Guimond, R. J., W. H. Ellett, J. Fitzgerald, and S. T. Windham. 1979. Indoor Radiation Exposure Due to Radium-226 in Fiorida Phosphate Lands. EPA-520/4-78-013, Office of Radiation Programs, U.S. Environmental Protection Agency, Las Vegas, Nevada.

Gulbrandsen, R. A. 1977. Byproduct Resources of Phosphate Ore of Southeastern Idaho. Abstract Programs (Boulder, Colorado).

Habashi, F. 1970. Uranium in Phosphate Rock. Special Publication 52, Montana Bureau of Mines and Geology, Montana College of Minerais Science and Technology, Butte, Montana.

Hans, J. M., G. G. Eadie, J. Thrall, and B. Peterson, 1978. Above Ground Gamma Ray Logging for Locating Structures and Areas Containing Elevated Levels of Uranium Decay Chain Radionuclides. ORP/LV-78-2, Office of Radiation Programs, U.S. Environmental Protection Agency, Las Vegas, Nevada.

Health Physics Society. 1983. Indoor Radon 45(2).

Horton, T. R. 1979. A Preliminary Radiological Assessment of Radon Exhalation from Phosphate Gypsum Piles and Inactive Uranium Mill Tailings Piles. EPA-520/5-79-004, U.S. Environmental Protection Agency, Washington, D.C. 
Hsieh, S. S., and J. R. Lehr. 1985. "Benefication of Dolomitic Idaho Phosphate Rock by the TVA Diphosphonic Acid Depressant Process." Minerals and Metallurgical Processing 2(1):10-13.

Hutchison, F., and C. M. Wai. 1979. "Cadmium, Lead, and Zinc in Reclaimed Phosphate Waste Dumps in Idaho." Bull. Environ. Contam. Toxicol. $23(3): 377-380$.

Hutchison, F., C. M. Wai, M. Jernegan, W. Hicks, and R. Long. 1979. "0istribution of Cadmium, Lead, and Zinc in Soil Around Two Phosphate Processing Plants in Pocatello, Idaho." Bull. Environ. Contam. Toxicol. 22(3):426-429.

Ida, R. B. 1980. Air Pollution Control Evaluation--FMC Corporation Elemental Phosphorus Plant, Pocate110, Idaho. EPA-330/2-80-027, U.S. Envi ronmental Protection Agency, Denver, Colorado.

Jeppson, R. W., and E. E. Farmer. 1980. "Composite Water Movement in a Sloping Phosphate Mine Dump." Symposium on Watershed Management 1980, American Society of Civil Engineers, Boise, Idaho.

Johnson, D. W., and J. C. Kent. 1978. The Source of American Falls Reservoir Pollutants. PB-287 628, National Technical Information Service, Springfield, Virginia.

Johnson, R., C. M. Wai, B. McVeety, H. Lee, and H. Willmes. 1980. "Uranium in Soil Around Phosphate Processing Plants in Pocatelio, Idaho." Bull. Environ. Contam. Toxicol. 24(5):735-738.

Jongleaux, R. F. 1984. Emission Testing of Calciner Off-Gases at FMC Elemental Phosphorus Plant, Pocatello Idaho, Volumes I \& II. Prepared for U.S. Environmental Protection Agency under Contract No. 68-02-3174 by Radian Corporation, Research Triangle Park, North Carolina.

Jongleaux, R. F. 1984. Emission Testing of Calciner 0ff-Gases at Monsanto Elemental Phosphorus Plant, Soda Springs, Idaho, Volumes I \& II. Prepared for U. S. Environmental Protection Agency under Contract No. 68-02-3174 by Radian Corporation, Research Triangle Park, North Carolina.

Jongleaux, R. F. 1984. Emission Testing of Calciner Off-Gases at Stauffer Elemental Phosphorus Plant, Silver Bow, Montana, Volumes I \& II. Prepared for U.S. Environmental Protection Agency under Contract No. 68-02-3174 by Radian Corporation, Research Triangle Park, North Carolina.

Knopp, C. M., and E. E. Farmer. 1980. Infiltration and Erosion Analysis of Phosphate Strip Mine Overburden. BUMINES-RI-8534, Intermountain Forest and Range Experiment Station, Ogden, Utah.

Krall, M. A., J. C. Frost, and R. L. Geddes. 1984. "Case Study of the Conda Partnership's Dry Valley Phosphate Mining Project." Presented at the Society of Mining Engineers-American Institute of Mining Engineers Fall Meeting, Denver, Colorado. 
Lardinoye, M. H., and K. Weterlings. 1982. "Unexpected 226 Rn Buildup in Wet Process Phosphoric Acid Plants." Health Physics 42:503-514.

Lindsey, A. M., and R. Segars. 1974. Control of Particulate Emissions from Phosphate Rock Dryers. U.S. Environmental Protection Agency, Region IV, AtTanta, Georgia.

Lloyd, L. L. 1983. Evaluation of Radon Sources and Phosphate Slag in Butte, Montana. EPA-520/6-83-026, U.S. Environmental Protection Agency, Washington, D.C.

Low, W. H. 1981. Radionuclide Concentrations in Streams in the Upper Blackfoot River Basin, Southeastern Idaho. U.S. Geological Survey, Boise, Idaho.

Lowder, W. M., A. C. George, C. V. Gogolak, and A. Blav. 1971. Indoor Radon Daughter and Radiation Measurements in East Tennessee and Central Florida. HASL TM-71-8, Health and Safety Laboratory, U.S. Atomic Energy Commission.

Mansfield, G. R. 1942. "Phosphate Resources of Florida." U.S. Geol. Survey Bul1. 934:82.

Marcus, L. L. 1979. "Methodology for Post-EIS (Environmental Impact Statement) Monitoring." U.S. Geological Survey Circular 782.

McNabb, G. J., J. A. Kirk, and J. L. Thompson. 1979. "Radionuclides from Phosphate-0re-Processing Plants: The Environmental Impact After 30 Years of Operation." Health Physics 37(4):585.

McNabb, G. J. 1977. Radioactivity in Soils: The Effects of Phosphate Processing. A thes is submitted in partial fulfillment for the degree of Master of Science in Physics-Chemistry, Idaho State University.

Melville, C. M., C. M. Wai, M. Collopy, and H. Willmes. 1981. "Uranium Dispersion Along Roads Paved with Phosphate Slag." Bull. Environ. Contam. Toxicol. 27(4):470-473.

Melville, C, 1980. Uranium in Idaho's Roadbeds Constructed of Phosphate Slag--Environmental Impacts and Recovery. NSF-SOS Project Report, Department of Chemistry, University of Idaho, Moscow, Idaho.

Menze1, R. G. 1968. "Uranium, Radium, and Thorium Content in Phosphate Rocks and Their Possible Radiation Hazard." J. Agr. Food Chem. 16(2):231-234.

Midwest Research Institute. 1975. Air Pollution Emission Test. Beker Industries, Inc. Prepared for U.S. Environmenta! Protection Agency, Office of Air and Waste Management under Contract No. 68-02-1403, Kansas City, Missouri. 
Midwest Research Institute. 1983. Source Test Plan for Radioactive Emission Testing of Phosphate Industry Calciner. Prepared for Eastern Environmental Radiation Facility, U.S. EnvironmentaT Protection Agency, Montgomery, Alabama, under Contract No. 68-02-3177, Kansas City, Missouri.

Midwest Research Institute. 1984. Analysis of Achievable Po-210 Emissions and Associated Costs for FMC's Pocatel To Idaho Plant. Prepared for U.S. Environmental Protection Agency under Contract No. 68-02-3817, Kansas City, Missouri.

Moore, R. E., C. F. Baes, III, L. M. McDowell-Boyer, A. P. Watson, F. 0. Hoffman, J. C. Pleasant, and C.W. Miller. 1979. AIRDOS-EPA: A Computerized Methodology for Estimating Environmental Concentrations and Dose to Man From Airborne Releases of Radionuclides. EPA-520/1-79-0D9, Office of Radiation Programs, U.S. Environmentai Protection Agency, Washington, D.C.

National Council on Radiation Protection \& Measurements. 1975. Natural Background Radiation in the United States. NCRP Report No. 45, Washington, D.C.

National Council on Radiation Protection \& Measurements. 1984. Exposures From the Uranium Series with Emphasis on Radon and its Daughters. NCRP Report No. 77 , Washington, D.C.

Nielson, J. 1982. Phosphate Mining and Geology at Gay Mine, Idaho. Northwest Geology, Missoula, Montana.

Oakley, D. T. 1972. Natural Radiation Exposure in the United States. ORP/SID-72-1, Office of Radiation Programs, U.S. Environmental Protection Agency, Washington, D.C.

O'Riordan, M. C., M. J. Duggan, W. B. Rose, and G. F. Bradford. 1972. The Radiological Implications of Using By-Product Gypsum as a Building Material. NRPB-R7, National Radiological Protection Board, Harwell, Didcot, Berks, London.

Pabst, M. 1979. "Idaho Mountains Yield 2 Million Tons of Phosphate Shale Per Year." Canadian Mining Journal 100(8):77.

Partridge, J. E., T. R. Horton, and E. L. Sensintaffar. 1978. Radiation Dose Effects Due to Air Particulate Emissions from Selected Phosphate Industry Operation. ORP/EERF-78-1, Office of Radiation Programs, U.S. Environmental Protection Agency, Washington, D.C.

Partridge, J. E., T. R. Horton, and E. L. Sensintaffar. 1979. A Study of Radon-222 Released from Water During Typical Household Activities. Technical Note ORP/EERF-79-1, Office of Radiation Programs, U.S. Environmental Protection Agency, Montgomery, Alabama.

PEDCo Environmenta], Inc. 1979. Collection of Airborne Radon and Radioactive Particulates at Stauffer Chemical Company--Emission Test Result. Silver Bow, Montana; Cincinnati, Ohio. 
PEDCo Environmental, Inc. 1983. Evaluation of Waste Management for Phosphate Processing: Interim Report on Characterization of Phosphate Processing Wastes and Selection of Management Practices and Sites to be Monitored. Prepared for U.S. Environmental Protection Agency under Contract No. 68-03-3036, Cincinnati, Ohio.

PEI Associates. 1985. Data Describing Phosphogypsum Piles. Prepared for U.S. Environmental Protection Agency under Contract No. 68-02-3878, Cincinnati, Ohio.

PEI Associates. 1986. Data Summary Report--Radionuclide Air Sampling at Florida Phosphogypsum Stacks. Prepared for U.S. Environmental Protection Agency under Contract No. 68-02-3878, Cincinnati, Ohio.

Poet, S. E., H. L. Moore, and E. A. Martel1. 1972. "Lead-210, Bismuth-210 and Polonium-210 in the Atmosphere." J. Geophys. Res. 77:6515.

Ralston, D. R. 1982. "Interaction of Hydrological and Mining Variables in the Western Phosphate Field, USA." Presented at the 1st International Mine Water Congress of the International Mine Water Association, Budapest, Hungary.

Ralston, D. R., M. R. Cannon, and G. V. Winter. 1979. "Ground Water Flow Systems in Idaho's Western Phosphate Field." First Proceedings of the International Mine Drain Symposium, Denver, Colorado.

Ralston, D. R., T. D. Brooks, M. R. Cannon, and T. F. Corbet, Jr. 1980. Interactions of Mining and Water Resource Systems in the Southeastern Idaho Phosphate Field. Prepared for the Office of Water Research and Technology, Washington, D.C., under Contract No. OWRT $\rightarrow \mathrm{C} \rightarrow 7651$.

Ralston, D. R., and R. E. Williams. 1979. "Groundwater Flow-Systems in the Western Phosphate Field in Idaho." Journal of Hydrology 43(1-4):239-264.

Ralston, D. R., and E. W. Trihey. 1975. "Distribution of Precipitation in Little Long Valley and Dry Valley, Caribou County, Idaho." Information Circular, Idaho Bureau of Mines and Geology.

Rhodes, J. A. 1975. "Review of the Western Phosphate Fieid." Special Publication 74:61-67, Montana Bureau of Mines and Geology.

Roessier, C. E., Z. A. Smith, W. E. Bolch, and R. J. Prince. "Uranium and Radium-226 in Florida Phosphate Materials." Health Physics 37(3):269-277.

Ronca-Battista, M., P. Magno, and S. Windham. 1986. "Uncertainties of Estimating Average Radon and Radon Decay Product Concentrations in Occupied Houses." Proceedings of Indoor Radon and Air Pollution Control Association Special Conference, Philadelphia, Pennsyivania.

Service, A. L. 1967. History and Development of the Phosphate Industry in Southeastern Idaho 15:175-185, Association of Petrologists and Geologists, Annual Field Conference (guidebook). 
Severson, R. C., and L. P. Gough. 1976. "Concentration and Distribution of Elements in Plants and Soils Near Phosphate Processing Factories, Pocatello, Idaho." Journal of Envi ronmental Quality 5(4):476-482.

Severson, R. C., and L. P. Gough. 1979. Environmental Implications of Element Emissions from Phosphate-Processing 0perations in Southeastern Idaho. Geological Survey Professional Paper 1083, U.S. Government Printing office, Washington, D.C.

Shearer, S., B. Smith, and D. E. Rushing. 1973. "Draft Report of Radium-226 and Radon-222 Concentrations in Central Florida Ground Waters." Appendix B in Reconnaissance Study of Radiochemical Pollution for Phosphate Rock Mining and Milling. U.S. Envi ronmental Protection Agency, National Field Inc. Center, Denver, Colorado, pp. Bl-29.

Singh, H., and D. Ralston. 1979. Construction and Application of a Water Quality Model for the Upper Blackfoot River Basin in the Caribou National Forest, Idaho. Prepared for the office of Water Research and Technology, Washington, D.C., under Contract No. OWRT-C-7651.

Smith, S. G. 1982. Particulate Emissions and Control Costs of Radionuclide Sources in Phosphate Rock Processing Plants. Prepared for U.S. Environmental Protection Agency under Contract No. 68-02-3515 by TRW Energy and Environmental Division, Research Triangle Park, North Carolina.

State of Idaho. 1977. "Technical Policy Memorandum No. 7 Concerning the Use of Radium-Contaminated Phosphate Slag in Idaho." Department of Health and Welfare, Boise, Idaho.

Steininger, E. 1974. "Utilization of By-Products fron the West Phosphoric Acid Production to Prevent Environmental Poliution." Expert Group Meeting on Minimizing Pollution from Fertilizer Plants, Helsinke, Finland, August 26-31, 1974.

Stowasser, W. F. 1976. "Phosphate Rock." Mineral Facts and Problems. U.S. Bureau of Mines Bulletin 667, pp. 319-834.

Stula, S., et al. 1983. Control Technology Alternatives and Costs for Cornpliance--Elemental Phosphorus Plants. Prepared for U.S. Environmental Protection Agency under Contract No. 68-01-6429 by Science Applications, Inc., La Jolla, California.

Sylvester, K. A. 1975. A Preliminary Evaluation of Ground Water in Upper Dry Valley and Little John Valley, Caribou County, Idaho. Idaho Bureau of Mines and Geology.

Texas Instruments, Inc. 1979. Aerial Radiometric and Magnetic Reconnaissance Survey of Portions of Arizona, Idaho, Montana, New Mexico, South Dakota and Washington. Volume 2-G. Prepared for Department of Energy under Contract No. EY-76-C-13-1664. 
Town, J. W., and P. E. Sanker. 1968. Evaluation of Phosphate Fines from Southeastern Idaho. RI-7205, U.S. Bureau of Mines, Washington, D.C.

U.S. Atomic Energy Commission. 1970. Pocatello and Vicinity Environmental Air Sampling Results for December 1969 through May 1970. Health Services Laboratory, Idaho Operations Office, Idaho Falls, Idaho.

U.S. Bureau of Mines. 1983. "Idaho Phosphate Deposits." 8926:224-292, Information Circular, U.S. Bureau of Mines, Washington, D.C.

U.S. Department of AgricuTture and U.S. Department of the Interior. 1982. Smoky Canyon Phosphate Mine, Caribou County, Idaho: Final Environmental Impact Statement. U.S. Department of Agriculture, Forest Service, Pocatello, Idaho.

U.S. Environmental Protection Agency. 1973. Reconnaissance Study of Radiochemical Pollution from Phosphate Rock Mining \& Milling. Office of Enforcement, National Field Investigations Center, Denver, Colorado.

U.S. Envi ronmental Protection Agency. 1974. Interim Radium-226 Effluent Guidelines for Phosphate Chemicals and Phosphate Fertilizer Manufacturing, Statement of Considerations. Office of Radiation Programs, washington, 0.C.

U.S. Environmental Protection Agency. 1975. Preliminary Findings--Radon Daughter Levels in Structures Constructed on Reclaimed Florida Phosphate Land. Technical Note 0RP/CSD-75-4, Criteria and Standards Division, Office of Radiation Programs, Washington, D.C.

U.S. Environmental Protection Agency. 1976. "Drinking Water Regulations (Radionuclides)." Federal Register 41(133):28402-28409.

U.S. Environmental Protection Agency. 1976. "Florida Phosphate Lands, Interim Recommendations for Radiation Levels." Federal Register 41(123):26066-26068.

U.S. Environmental Protection Agency. 1976. Radiation Dose Estimates to Phosphate Industry Personnel. EPA-520/5-76-014, Office of Radiation Programs, Washington, D.C.

U.S. Environmental Protection Agency. 1977. Effects of Phosphate Mineralization and the Phosphate Industry on Radium-226 in Ground Water of Central Florida. EPA-520/6-77-010, Office of Radiation Programs, Las Vegas, Nevada.

U.S. Environmental Protection Agency. 1978. Air Pollutant Control Techniques for Phosphate Rock Processing Industry. EPA-450/3-78-030, Office of Air Quality Planning and Standards, Research Triangle Park, North Carolina.

U.S. Environmental Protection Agency. 1979. Indoor Radiation Exposure Due to Radium-226 in Florida Phosphate Lands. EPA-520/4-78-013, 0ffice of Radiation Programs, Washington, D.C. 
U.S. Environmental Protection Agency. 1979. Radiological Impact Caused by Emissions of Radionuclides into Air in the United States--Preliminary Report. EPA-520/7-79-006, Office of Radiation Programs, Washington, 0.C.

U.S. Environmental Protection Agency. 1982. Emissions of Naturally Occurring Radioactivity: Monsanto Elemental Phosphorus Plant. EPA-520/6-82-021, Office of Radiation Programs, Las Vegas, Nevada.

U.S. Environmental Protection Agency. 1982. Emissions of Naturally Occurring Radioactivity: Stauffer Elemental Phosphorus Plant. EPA-520/6-82-019, Office of Radiation Programs, Las Vegas, Nevada.

U.S. Environmental Protection Agency. 1982. Phosphate Rock Plants--Background Information for Promulgated Standards. EPA-450/3-79-017b, pp. 2-15-2-20.

U.S. Environmental Protection Agency. 1983. Draft, Background Information Document Proposed Standards for Radionuclides. EPA-520/1-83-001, Office of Radiation Programs, Washington, D.C.

U. S. Envi ronmental Protection Agency. 1984. Background Information Document (Integrated Risk Assessment) Final Rules for Radionuclides--Volume I. EPA-520/1-84-022-1, Office of Radiation Programs, Washington, D.C.

U. S. Environmental Protection Agency. 1984. Background Information Document (Integrated Risk Assessment) Final Rules for Radionuclides--Volume II. EPA-520/1-84-022-2, Office of Radiation Programs, Washington, D.C.

U.S. Envi ronmental Protection Agency. 1984. Emissions of Lead-210 and Polonium-210 from Calciners at Elemental Phosphorus Plants: FMC Plant, Pocatello, Idaho. Office of Radiation Programs, Washington, D.C.

U.S. Environmenta? Protection Agency. 1984. Emissions of Lead-210 and Polonium-210 from Calciners at Elemental Phosphorus Plants: Monsanto Plant Soda Springs, Idaho. Office of Radiation Programs, Washington, D.C.

U.S. Environmental Protection Agency. 1984. Emissions of Lead-210 and Polonium-210 from Calciners at Elemental Phosphorus Plants: Stauffer Plant, Silver Bow, Montana. Office of Radiation Programs, Washington, D.C.

U.S. Environmental Protection Agency. 1984. Regulatory Impact Analysis of Emission Standards for Elemental Phosphorus Plants. EPA-520/1-84-025, Office of Radiation Programs, Washington, D.C.

U.S. Environmental Protection Agency. 1987. Emissions of Lead-210 and Polonium-210 from Phosphate Rock Calciners at Wet-Process Fertilizer Plants: J. R. Simplot Plant, Pocatello, Idaho. Office of Radiation Programs, Washington, D.C. 
U.S. House of Representatives. 1983. EPA Radon and Radionuclide Emission Standards. Hearings before the Procurement and Military Nuclear Systems Subcommittee of the Committee on Armed Services. H.A.S.C. No. 98-11, October 6, 1983.

Winter, G. V., and D. R. Ralston. 1979. "Ground Water Flow Systems in the "Phosphate Sequence' of Southeastern Idaho." Proceedings of the 17th Annual Engineering Geology and Soils Engineering Symposjum, University of Idaho, Moscow, Idaho.

Winter, G. V. 1980. Ground Water Flow Systems in the Phosphate Sequence, Caribou County, Idaho. Prepared for the Office of Water Research and Technology, Washington, D.C., under Contract No. OWRT-C-765l. 
DISTR IBUTION

No. of

Copies

OFFSITE

\section{DOE Technical Information Center}

D. T. Abbot

Monsanto Research Corp.

P.0. Box 32

Miamisburg, $\mathrm{OH} 45342$

G. A. Abel

U.S. Environmental Protection Agency

Region 10

$1200 \mathrm{Sixth}$ Avenue

Seattle, WA 98101

W. A. Bliss

U.S. Environmental Protection Agency

Office of Radiation

Programs - LVF

P.0. Box 98517

Las Vegas, NV 89193-8517

M. E. Bowman

FMC Corporation

Phosphorus Chemicals Division P.0. Box 4111

Pocatello, ID 83202

K. Brooks

Idaho Department of Health and Welfare

Radiation Control Section

Statehouse Mail

Boise, IO 83720

G. Burley

U.S. Environmental Protection Agency

Office of Radiation Programs

401 "M" Street, S.W.

Washington, DC 20460
No. of

Copies

C. Chicon

The Shoshone-Bannock Tribe

P. 0 . Box 306

Fort Hall, ID 83203

J. Cochrane

J. R. Simplot Company

Minerals \& Chemical Division

P.O. Box 912

Pocatello, I0 83204

A. L. Cole

The State of Idaho

Division of Environment

Dept. of Health \& WeIfare

150 North 3rd

Pocatello, ID 83201

8 K. Conway

EPA Science Advisory Board

c/o U.S. Environmental

Protection Agency

Office of Radiation Programs (ANR-458)

401 "M" Street, S.W.

Washington, DC 20460

Forward to SAB Committee

2 R. S. Finlayson, Mayor

City of Pocatello

P.0. Box 4169

Pocatello, ID 83205

B. Frost

The Shoshone-Bannock Tribe

P.0. Box 306

Fort Hall, ID 83203

R. L. Geddes

Monsanto Chemical Co. Detergents Division

Soda Springs Plant

P.0. Box 816

Soda Springs, ID 83276 
No. of

Copies

M. C. Godwin

J. R. Simplot Company

Minerals \& Chemical Division

P.0. Box 912

Pocatello, ID 83204

R. A. Griffin

Kerr-McGee Chemical Corporation

P.0. Box 478

Soda Springs, ID 83276

P. B. Hahn

U.S. Environmental Protection Agency

Office of Radiation

Programs-LVF

P.0. Box 98517

Las Vegas, NV 89193-8517

J. M. Hardin

U.S. Environmental Protection Agency

Office of Radiation Programs

401 "M" Street, S.W.

Washington, DC 20460

J. P. Hyland (G-4WT)

Monsanto Chemical Co.

800 N. Lindbergh Blvd.

St. Louis, MO 63167

Idaho State University

Library

741 S. Seventh Avenue

Pocatello, I0 83209

R. H. Jacobson

U.S. Environmental Protection Agency

Region 10

1200 Sixth Avenue

Seattle, WA 98101
No. of

Copies

M. N. Kahn

U.S. Environmental Protection Agency

Office of Radiation Programs

401 "M" Street, S.W.

Wastington, DC 20460

C. Koshuta

Idaho Department of Health and Welfare

Radiation Control Section

Statehouse Mail

Boise, ID 83720

J. M. Leitch

U.S. Environmental Protection Agency

Region 10

1200 Sixth Avenue

Seattle, WA 98101

K. V. Lott

Monsanto Chemical Co.

Detergents Division

Soda Springs Plant

P.0. Box 816

Soda Springs, I0 83276

R. J. Lyon

U.S. Environmental Protection Agency

Office of Radiation

Programs - LVF

P.0. Box 98517

Las Vegas, NV 89193-8517

E. C. Mapes

J. R. Simplot Company

Minerals \& Chemical Division

P.0. Box 912

Pocatel10, ID 83204

P. J. Magno

U.S. Environmental Protection Agency

Office of Radiation Programs

401 "M" Street, S.W.

Washington, DC 20460 
No. of

Copies

M. T. Masarik

U.S. Environmental Protection Agency

Region 10

422 W. Washington

Boise, ID 83702

T. A. Mclaughlin

U.S. Environmental Protection Agency

Office of Radiation Programs

401 "M" Street, S.W.

Washington, DC 20460

J. C. Meredith

Idaho Conservation League

P.0. Box 546

Pocatello, ID 83204

S. Meyers

U.S. Environmenta? Protection Agency

Office of Radiation Programs

401 "M" Street, S.W.

Washington, DC 20460

W. S. Moore

FMC Corporation

Phosphorus Chemicals Division P.0. Box 4111

Pocatello, ID 83204

A. L. Odmark

U.S. Environmental Protection Agency

Region 10

422 W. Washington

Boise, ID 83702

G. L. O'Neal

U.S. Environmental Protection Agency

Region 10

1200 Sixth Avenue

Seattle, WA 98101
No. of

Copies

J. Palmer

Southeastern District Health Department

P.0. Box 83205

Pocatello, ID 83205

J. G. Peterson

Idaho Mining Association

P.0. Box 1660

Boise, ID 83701

C. R. Phillips

U.S. Environmental Protection Agency

Eastern Environmental Radiation Facility 1890 Federal Drive

Montgomery, AL 36109

2 Pocatello Public Library

City Hall

902 E. Sherman Street

Pocatello, ID 83201

C. R. Porter

U.S. Environmental Protection Agency

Eastern Environmental Radiation Facility

1890 Federal Drive

Montgomery, AL 36109

6 C. H. Schmidt

City Administrator

City of Soda Springs

9 West 2nd South

Soda Springs, ID 83276

C. L. Sikorski

U.S. Environmental Protection Agency

Region 10

1200 Sixth Avenue

Seattle, WA 98101 
No. of

Copies

S. M. Smart

City of Chubbuck

5160 Yellowstone Avenue

Chubbuck, ID 83202

2 Soda Springs Public Library

Soda Springs, ID 83276

M. Torf

Idaho Department of Health and Welfare

Radiation Control Section

Statehouse Mail

Boise, ID 83720

S. T. Windham

U.S. Environmental Protection Agency

Eastern Environmenta] Radiation Facility

1890 Federal Orive

Montgomery, AL 36109
No. of

Copies

ONSITE

DOE Richland Operations Office

J. J. Sutey

29 Pacific Northwest Laboratory

E. G. Baker

H. D. Freeman (20)

J. N. Hartley

Publishing Coordination (2)

Technical Report Files (5) 